\title{
POWER SECTOR DEVELOPMENT IN MYANMAR
}

Kee-Yung Nam, Maria Rowena Cham, and Paulo Rodelio Halili

NO. 460

October 2015
ADB ECONOMICS WORKING PAPER SERIES 


\section{ADB Economics Working Paper Series}

\section{Power Sector Development in Myanmar}

Kee-Yung Nam, Maria Rowena Cham, and Paulo Rodelio Halili

No.460 | October 2015
Kee-Yung Nam (kynam@adb.org) is Principal Economist, Maria Rowena Cham (rmcham@adb.org) is Senior Economics Officer, and Paulo Rodelio Halili (phalili@adb.org) is Senior Economics Officer at the Economic Research and Regional Cooperation Department, Asian Development Bank (ADB).

This paper was written as a background paper for the ADB Myanmar Country Diagnostics Study. The authors wish to thank Ron Ico, Lyndree Malang, and Lotis Quiao for their excellent research support. 
Asian Development Bank

6 ADB Avenue, Mandaluyong City

1550 Metro Manila, Philippines

www.adb.org

(C) 2015 by Asian Development Bank

October 2015

ISSN 2313-6537 (Print), 2313-6545 (e-ISSN)

Publication Stock No. WPS157710-2

The views expressed in this paper are those of the authors and do not necessarily reflect the views and policies of the Asian Development Bank (ADB) or its Board of Governors or the governments they represent.

ADB does not guarantee the accuracy of the data included in this publication and accepts no responsibility for any consequence of their use.

By making any designation of or reference to a particular territory or geographic area, or by using the term "country" in this document, $A D B$ does not intend to make any judgments as to the legal or other status of any territory or area.

Note: In this publication, "\$” refers to US dollars.

The ADB Economics Working Paper Series is a forum for stimulating discussion and eliciting feedback on ongoing and recently completed research and policy studies undertaken by the Asian Development Bank (ADB) staff, consultants, or resource persons. The series deals with key economic and development problems, particularly those facing the Asia and Pacific region; as well as conceptual, analytical, or methodological issues relating to project/program economic analysis, and statistical data and measurement. The series aims to enhance the knowledge on Asia's development and policy challenges; strengthen analytical rigor and quality of ADB's country partnership strategies, and its subregional and country operations; and improve the quality and availability of statistical data and development indicators for monitoring development effectiveness.

The ADB Economics Working Paper Series is a quick-disseminating, informal publication whose titles could subsequently be revised for publication as articles in professional journals or chapters in books. The series is maintained by the Economic Research and Regional Cooperation Department. 


\section{CONTENTS}

TABLES AND FIGURES

ABSTRACT

$\begin{array}{ll}\text { I. INTRODUCTION } & 1\end{array}$

II. MYANMAR'S POWER SECTOR 2

A. $\quad$ Primary Energy Supply 3

B. Final Energy Consumption 3

III. INSTITUTIONAL STRUCTURE OF THE POWER SECTOR

A. $\quad$ Policies and Relevant Laws 5

B. Institutional Organization 6

IV. $\quad$ STATUS AND TRENDS IN THE POWER SECTOR 8

A. Capacity and Generation 8

B. Transmission and Distribution System 13

V. POWER SECTOR CONSTRAINTS

A. Limited, Unreliable Supply of Electricity Constrains Private Investment
and Affects the General Population

B. Limited Electricity Access Hinders Inclusive Growth 16

C. $\quad$ Electricity is Largely Affordable, but Low Cost is Unsustainable in the Long Run 17

D. Absence of Systematic Planning and Programming, Poor Governance, and Inadequate Funding Aggravate the Inefficient Management of the Sector $\quad 19$

$\begin{array}{ll}\text { VI. RECOMMENDATIONS } & 20\end{array}$

A. Establish the Governance and Institutions to Effectively Oversee
and Manage the Sector

B. Prepare and Implement a Least Cost Power Expansion Plan for Power Sector Development $\quad 21$

C. Aim for Sustainable Electrification $\quad 22$

D. Augment Investments in the Power Sector $\quad 22$

E. Improve Access to Electricity $\quad 22$

VII. DEMAND AND INVESTMENT GAPIN MYANMAR POWER INFRASTRUCTURE 22

A. Methodology and Data 23

B. Results 23

$\begin{array}{lr}\text { APPENDIXES } & 25\end{array}$

$\begin{array}{lr}\text { REFERENCES } & 29\end{array}$ 


\section{TABLES AND FIGURES}

\section{TABLES}

1 Installed Capacity and Generation 9

$2 \quad$ Peak Load in Region and State, 2013

3 Hydropower Resources 11

$4 \quad$ Hydropower Potential by River Basin 12

$5 \quad$ Potential Hydropower Plants near Myanmar's Borders 12

$6 \quad$ Existing Transmission Lines, 2013

$7 \quad$ Transmission Losses 14

$8 \quad$ Existing Distribution Lines and Substations, 2013

9 Distribution Losses $\quad 15$

10 Power Consumption in Region and State, 2013

$11 \quad$ Unit Cost of Power Infrastructure Services 23

12 Need Gaps from Projections of Power Infrastructure Stock Levels with

Baseline Stock of 1.7 Gigawatts in 2010

13 Power Investment Gaps from New Capacity and Replacement Needs, 2014-2030 24

\section{FIGURES}

1 Electricity Use per Capita in Selected ASEAN Countries, 2013

2 Myanmar's Total Primary Energy Supply, 2000-2013 3

3 Myanmar's Total Final Energy Consumption by Source, 2000-2013 4

4 Myanmar's Total Final Energy Consumption by Sector, 2000-2012 4

5 Organization and Function of the Ministry of Electric Power 8

6 Installed Capacity by Fuel Type 9

$7 \quad$ Electricity Generation by Fuel Type 10

$8 \quad$ Growth in Peak Load 10

$9 \quad$ Electrification as of December 2013

10 Average Electricity Tariff in ASEAN Countries 18 


\begin{abstract}
While the economic literature has yet to establish whether greater electricity consumption leads to faster economic growth, or vice versa, it is widely accepted that the better provision of electricity can enable pro-poor growth. Because electricity consumption is expected to grow in emerging economies such as Myanmar, it is important that the government prioritize its stable, efficient, and affordable supply. This paper assesses Myanmar's electricity sector and recommends several concrete policy options to enable government to address issues such as supply security, greater accessibility, and affordability, especially for the poor and disadvantaged. The paper also estimates infrastructure demand and the corresponding investment requirements to narrow the supply gap in the power sector.
\end{abstract}

Keywords: electricity access, Myanmar, power investment gap, power sector development, supply security

JEL Classification: H54, L94, Q43, Q47 


\section{INTRODUCTION}

As a key infrastructure component, electricity is vital to social and economic development. Its support of wide-ranging activities and services improves quality of life, increases labor productivity, and encourages entrepreneurial activity. Its stable supply of power allows households to improve living conditions, helping to meet heating, lighting, and cooking needs across income levels. And it is a key input in economic production, making goods and services across all economic sectors possible. It is also vital to basic social services such as education, health care, clean water supply, and sanitation. As such, access to affordable electricity can help developing countries meet the United Nations Millennium Development Goals.

But the economic literature has yet to establish whether greater electricity consumption leads to economic growth, or where economic growth leads to more electricity consumption. Likewise, it is difficult to estimate the magnitude of the impact of greater access to electricity on poverty, since having electricity is not an end in itself. Electricity needs to work with other sectors to ensure that the poor benefit as much as possible from that improved access.

Even without the availability of such evidence, it is widely accepted that better access to reliable and affordable electricity can enable pro-poor growth. The poor spend considerable time and financial resources on basic energy-related needs, constraining their pursuit of other productive activities. For example, in health care and education, electricity allows health clinics to provide treatment even after sunset and children to attend school. It frees up time otherwise spent on household and other chores and, importantly, allows study after sundown. In addition, electricity produced using "cleaner" technologies, reduces environmental damage and will mitigate the harmful effects of dirtier traditional fuel sources on poor people's health and livelihoods.

Because Myanmar's consumption of electricity is expected to grow, the government should prioritize its stable, efficient, and affordable supply. While the country has abundant energy resources, including renewable alternatives, hydropower remains the main source of fuel for electricity requirements, followed by natural gas and coal. Although the country's electricity consumption increased sharply between 2000 (3.5 terawatt hours [TWh]) and 2013 (10.1 TWh), its per capita electricity consumption (160 kWh in 2013) is still one of the lowest among its regional peers.' It is estimated that around 10-15 million people still have no access to electricity and around 12 million rely on traditional biomass for lighting and cooking.

This paper assesses Myanmar's electricity sector and recommends concrete policies to enable government to address issues such as supply security and sustained affordable access to electricity, especially for the poor and disadvantaged. Section II reviews the Myanmar power sector, Section III looks at the current institutional set up, and Section IV discusses status and trends. Section $V$ presents issues and constraints and Section VI lists short- and medium-term policy recommendations. Section VII estimates infrastructure demand and investment requirements to narrow the gap in its supply in the power sector.

Electricity consumption for 2000 is from the International Energy Agency (IEA) database (accessed 24 April 2014), while electricity consumption for 2013 is from ADB (Forthcoming). 


\section{MYANMAR'S POWER SECTOR}

Per capita electricity consumption in Myanmar remains among the lowest in Southeast Asia (Figure 1), reflecting poverty-level per capita incomes and an electrification rate of only 31\% as of December 2013 (ADB 2013a), and much less in most rural areas. Myanmar typifies a country saddled with "energy poverty" (IEA 2012). Lacking electricity, most rural households burn firewood and animal dung for lighting and cooking, causing widespread acute respiratory problems. Low electrification also hampers development of industry and even small businesses. The country therefore aims to develop and exploit its energy resources to increase the supply and reliability of electricity, particularly in rural areas, and accelerate overall economic development.

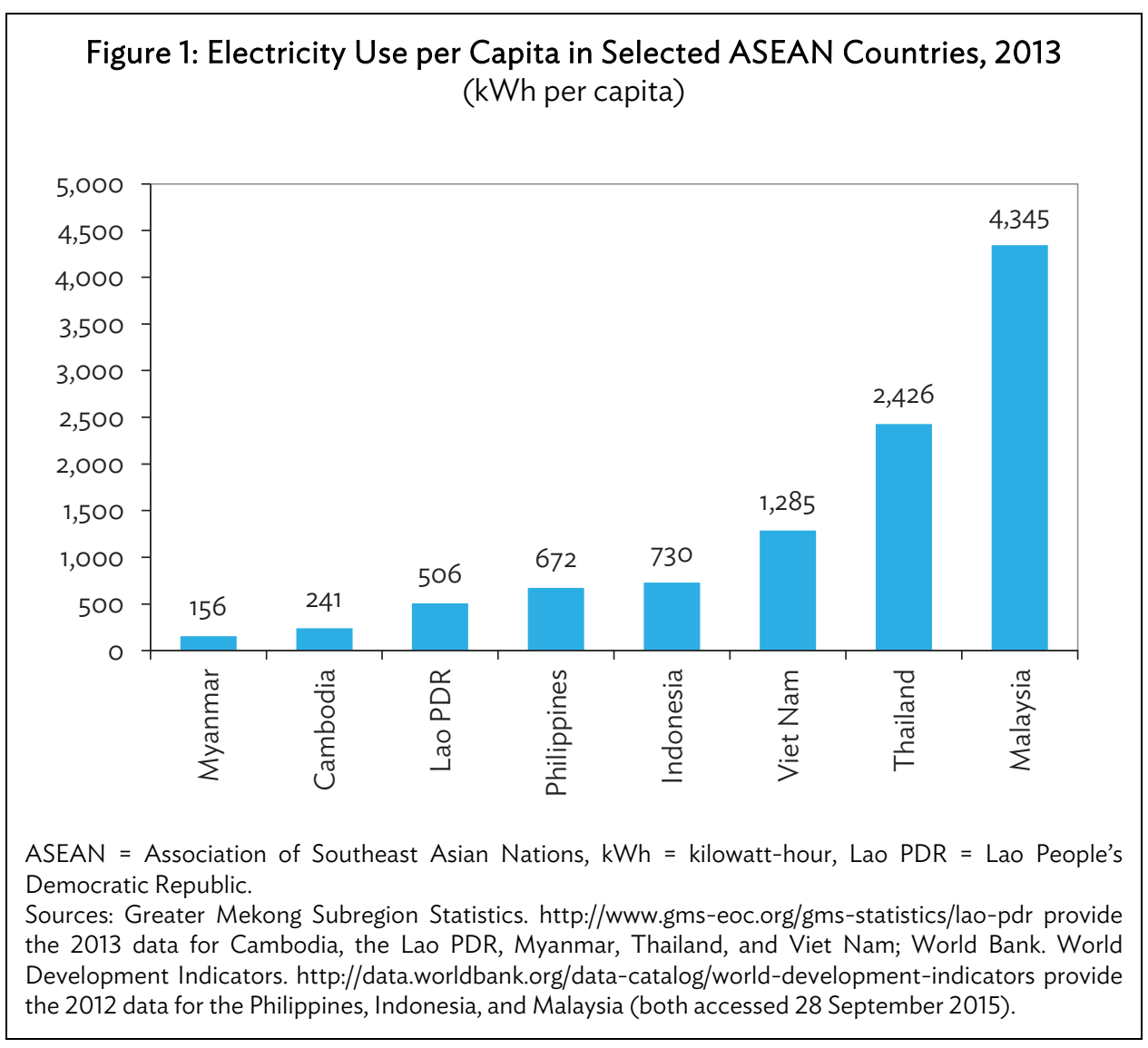

Myanmar has abundant energy resources, particularly hydropower and natural gas. The country's rivers can produce more than 100,000 megawatts (MW) of power once developed. The government has identified 92 potential large hydropower projects (each with at least $10 \mathrm{MW}$ capacity) with total potential installed capacity of 46,101 MW (WEF, ADB, and Accenture 2013). Proven gas reserves were estimated at 20.11 trillion cubic feet in 2012 (ADB 2013a), with huge potential for exploration. Offshore gas in the Yadana and Yetagun fields, both in the Andaman Sea, is the country's most important source of export revenues. Gas is now exported to Thailand, and will also be exported to the People's Republic of China (PRC) once a gas pipeline is constructed. In 2014, about $40 \%$ the country's approved foreign direct investment of $\$ 8$ billion was in the oil and gas sector (DICA). And Myanmar is one of five major energy exporters in the region, particularly of natural gas. Coal reserves are estimated at around 489 million tons (ADB 2013a). 


\section{A. Primary Energy Supply}

Total primary energy supply-coal, oil, gas, hydropower, and biomass-was about 18 million tons of oil equivalent (MTOE) in 2012-2013 (Figure 2). More than half (54\% or 9.7 MTOE) of Myanmar's energy supply was from biomass, followed by 17\% (3 MTOE) from hydro, 15\% (2.8 MTOE) from oil, and 12\% from gas. Coal accounted for only a small share (3\%). Hydropower production has expanded rapidly (12\% average annual increase from 2000 to 2013) whose share has since then significantly increased due to the commissioning of several hydropower plants. In 2013, coal accounts for $2.6 \%$ (0.475 MTOE) and has been at the same level for the last 5 years. Investments in hydropower and coalpowered plants, gas fields, and oil and gas pipelines are gaining ground, an indicator of a highly vibrant sector. And energy exports in 2011 were the equivalent of 8.6 MTOE, or more than half of total energy supply. ${ }^{2}$ Most of the produced gas is intended for export, which accounts for $78.8 \%$ in 2012 . It generated $\$ 2.1$ billion export revenue in the first half of fiscal year 2014 .

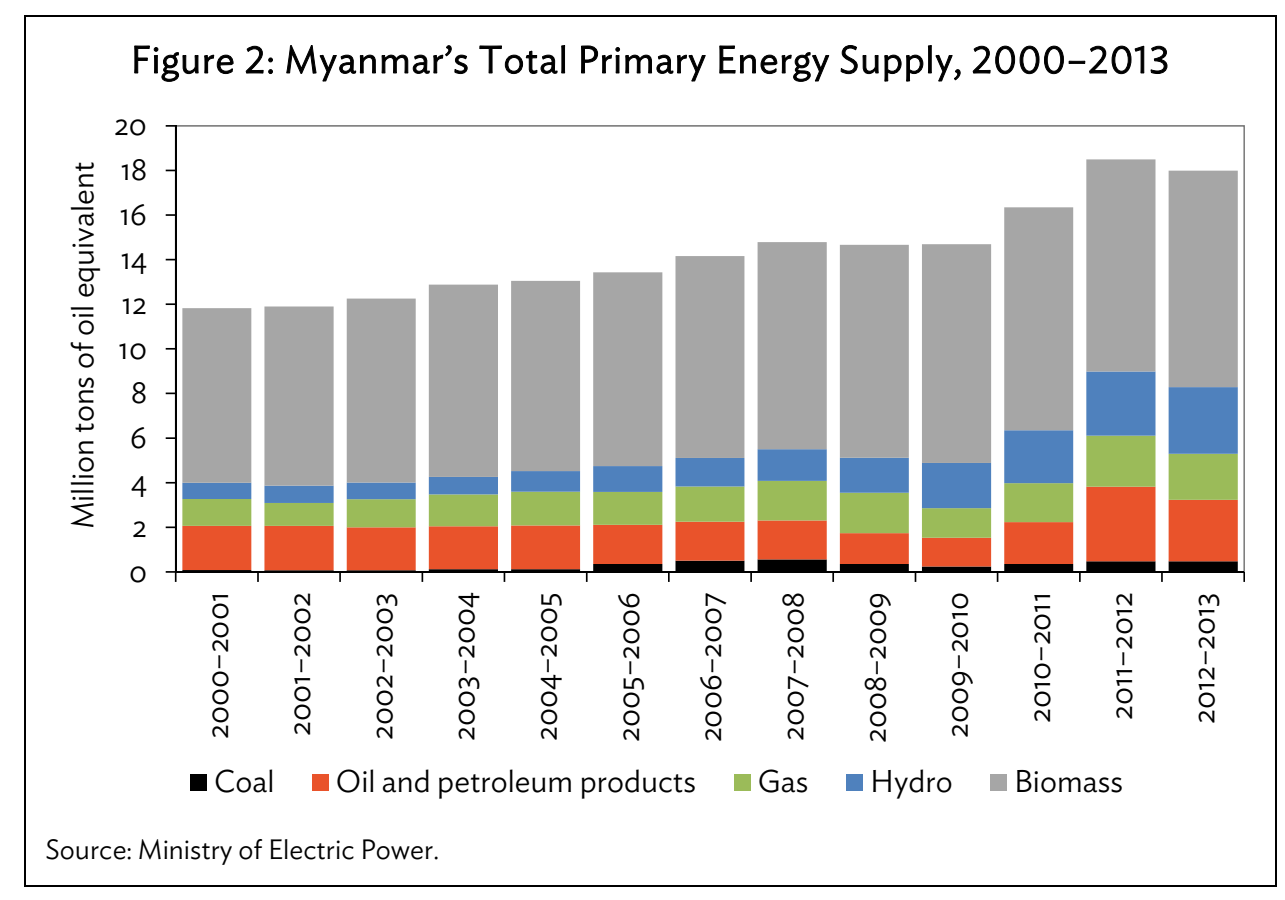

\section{B. Final Energy Consumption}

Overall, final energy consumption in Myanmar increased during 2000-2013 by an average of 1.9\% annually, from 10.1 MTOE to 12.6 MTOE. Figure 3 shows that energy consumption by fuel type is shifting toward coal, which increased $11 \%$ on average annually during the period. Natural gas grew $2.6 \%$ annually, and biomass only $1.9 \%$. But the latter remained the main source of energy consumption at $77 \%$ in $2012-2013$.

2 Data from the International Energy Agency database, accessed 26 February 2014. 


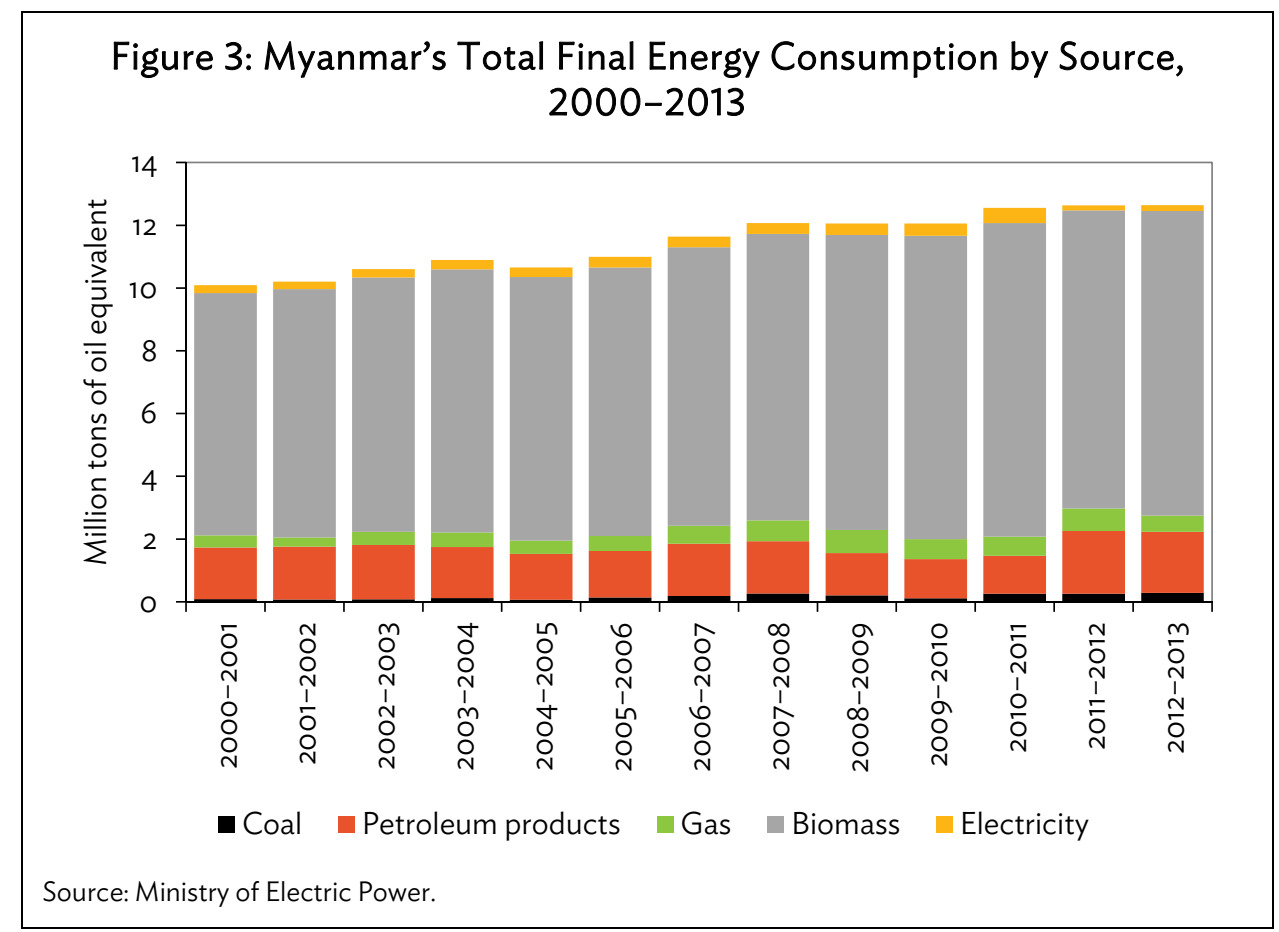

In energy consumption by sector (Figure 4), residential remains the largest consumer, with $74 \%$ of the total in 2012 - mainly in the form of biomass (fuel wood and charcoal). During 2000-2012, the commercial sector grew most, at $8.6 \%$ annual average, followed by the industrial (3.6\%) and residential sectors (1.6\%). Consumption in the agriculture and transport sectors contracted $3.6 \%$ and $0.7 \%$, respectively, during the same period.

\section{Figure 4: Myanmar's Total Final Energy Consumption by Sector, 2000-2012}

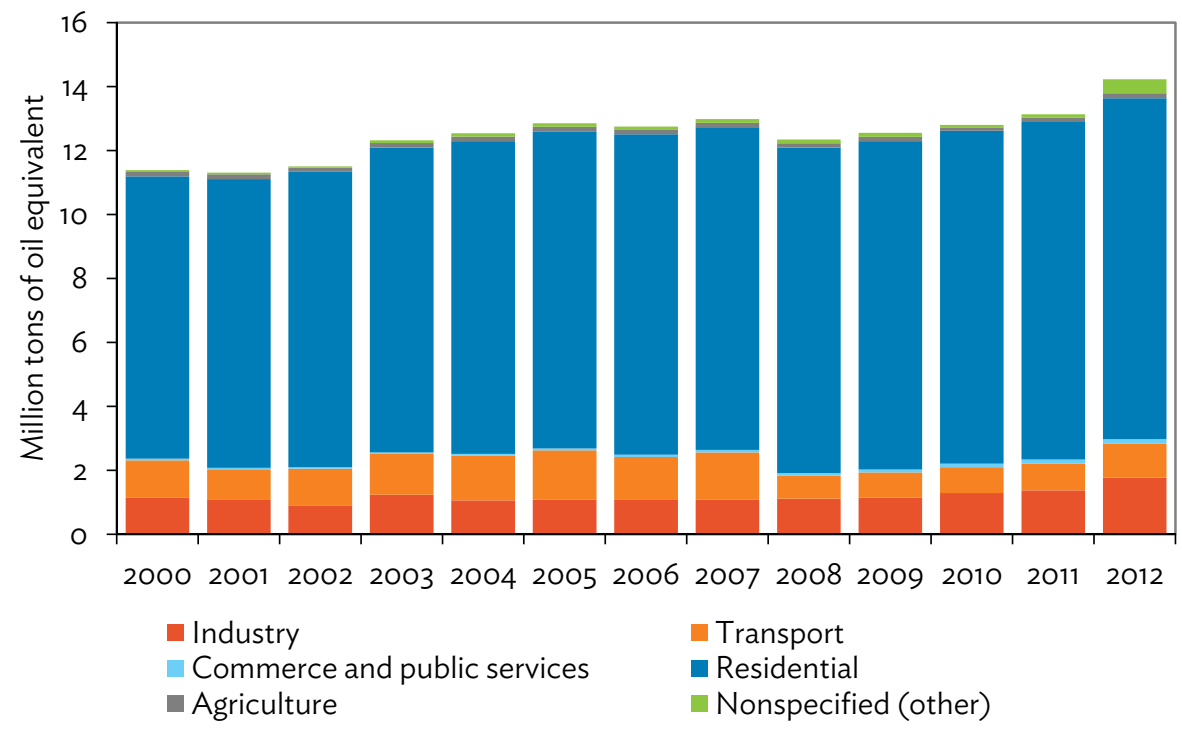

Source: International Energy Agency database (accessed 28 September 2015). 


\section{INSTITUTIONAL STRUCTURE OF THE POWER SECTOR}

\section{A. Policies and Relevant Laws}

The following laws govern the power sector:

(i) Electricity Act of 1948, as amended in 1967.

(ii) Myanmar Electricity Law (1984), which sets the requirements for the electricity authority, the duties and responsibilities of electricity inspectors, and the punishments and fines for various offences, and empowers the government to grant rights to specified organizations, including foreigners to participate within the sector (Webb 2013).

(iii) Electricity Rules (1985), which supplements the 1984 law.

(iv) Myanmar Electricity Law of 2014, which repeals that of 1984 and establishes the Electricity Regulatory Commission (ERC) and grants some regulatory responsibilities to the ERC; and authorizes the Ministry of Electric Power (MOEP), region and state governments, and leading bodies of self-administrated zones and self-administrated divisions the power to grant permits to entities to engage in electricity-related works such as generation, transmission, and distribution, thereby encouraging foreign and domestic investments in power projects.

Lui, Nair, and Paisner (2013) note that the 1984 law provides limited guidance on the rights and duties of the electricity license holder and is particularly silent on the responsibilities of public institutions, the licensing and approval process for investments in the sector, and the principles and procedure in tariff setting and dispute resolution.

Existing power sector policies cover the following:

(i) expand the national power grid for effective utilization of generated power from the available energy resources such as hydro, wind, solar, thermal, and other alternative ones to achieve sufficient electricity supply throughout the country;

(ii) conduct electricity generation and distribution in accordance with advanced technologies, and enhance private participation in regional distribution activities;

(iii) conduct Environmental and Social Impact Assessments for power generation and transmission projects in order to minimize negative impacts;

(iv) restructure the power sector with the cooperation of boards, private companies, and regional organizations toward more participation of local and foreign investments and formation of competitive power utilities;

(v) encourage the expansion of power transmission and distribution throughout the country and the employment of Public-Private Partnership in each sector; and

(vi) reach millennium development goals in areas covering construction of thermal power plants and more hydropower plants.

To achieve energy sustainability, the government aims to increase electricity generation from renewable energy resources. It sees these as vital to electrifying rural areas and therefore promotes (i) capacity building of those involved in renewable energy generation activities, (ii) awareness of alternative renewable energy sources, (iii) public-private partnerships and foreign investment for implementing renewable energy-related business, (iv) research and development of renewable energy, and $(v)$ energy efficiency. 
The government also recognizes that foreign direct investment through the private sector will be one of the main vehicles to develop the power sector. In the absence of a comprehensive and transparent framework for increased private sector participation in the sector, the government has taken initial steps to strengthen legislation to facilitate the financing of power investments through various private sector participation schemes with the provisions in the new Electricity Law. The provisions include, among other things, identification of required institutions and their own distinct and respective functions, preparation of a national electricity master plan, formulation of grid codes, and development of a framework or of model power purchase agreements for small and large power generation projects. To date, over $200 \mathrm{MW}$ of private sector power plants have been operational. And memoranda of understanding with about 50 companies covering hydro and thermal power plants are under consideration.

As in other countries that have implemented power sector reform, the identification and establishment of a regulatory body will play a central role in the strategic development of the sector. Tariff determinations, however, remain vested with MOEP and region or state governments, while the ERC may give advice to MOEP and the region and state governments and leading bodies with respect to electricity rates but may not set the rates. To operationalize the provisions in the new law, secondary legislation and implementing rules and regulations will have to follow, drafting of which may be completed by end 2015.

\section{B. Institutional Organization}

Eight ministries are responsible for energy matters in Myanmar. The Ministry of Energy, the overarching focal point, oversees overall energy policy in the oil and gas sector. The MOEP, the other key ministry, which oversees policy formulation in the sector, has the following responsibilities:

(i) development, implementation, operation and maintenance of all large hydropower plants;

(ii) development, implementation, operation and maintenance of coal-fired thermal power plants;

(iii) construction, operation, and maintenance of the transmission and distribution systems throughout the country;

(iv) operation and maintenance of gas-fired thermal power generation; and

(v) planning, implementation, and operation of minihydropower plants. ${ }^{3}$

To strengthen coordination and planning among the energy sector's institutions, the government in January 2013 established the National Energy Management Committee and the Energy Development Committee to improve resource planning and oversee investment in electricity sector development. ${ }^{4}$

The minister-level National Energy Management Committee, sitting under vice president no. 2 , formulates energy policy and plans in coordination with key energy-related ministries. The Energy Development Committee, composed primarily of deputy ministers, is responsible for implementing the National Energy Management Committee's policies and plans. The national committee's secretariat is

3 The Ministry of Energy's list of responsibilities was taken from ADB (2013b). The Ministry of Electric Power 1 and Ministry of Electric Power 2 were merged into one ministry in September 2012. The first was responsible for coal and large hydropower generation and the second for power transmission and distribution, gas-fired generation, and minihydro.

4 Appendix 1 details the responsibilities of the other six ministries involved in the energy sector. 
composed of staff seconded from the energy-related ministries, and the deputy minister for energy supervises its daily operation.

The regulatory framework and accompanying institutions specific to the sector's regulation have yet to be established, meaning that transition to a competitive market or any functional unbundling necessary to allow more efficient and reliable service has not taken place. The government is therefore reviewing the Electricity Law with an eye to including amendments that can address issues relating to supply security, electricity pricing, and equitable access to good quality service.

The MOEP has seven departments, three mainly operating entities-Myanmar Electric Power Enterprise, Yangon City Electricity Supply Board, and Electric Supply Enterprise (Figure 5). The departments have the following functions:

(i) Myanmar Electric Power Enterprise develops and implements the transmission network, including operation and maintenance, low voltage distribution system, and the operation and maintenance of gas-fired power plants (gas turbines and combined-cycle gas turbines). The transmission network voltage levels under its responsibility: existing 66 kilovolt (kV), $132 \mathrm{kV}$, and $230 \mathrm{kV}$; and the planned $500 \mathrm{kV}$ (under construction in four phases). The distribution systems consist of lower voltage levels, namely: 33 kV, 11 kV, 6.6 $\mathrm{kV}$, and $0.4 \mathrm{kV}$.

(ii) Yangon City Electricity Supply Board (YESB) is responsible for the supply of electricity to consumers in Yangon City. On 1 April 2015, however, the YESB has been corporatized into state-owned Yangon City Electricity Supply Corporation, financially independent from MOEP. Full privatization is planned within the next 3 to 4 years.

(iii) Electric Supply Enterprise covers the supply of power to the rest of the country, which comprises 17 states and regions, including off-grid generation and distribution. It is also responsible for planning, implementation, and operation of off-grid minihydropower and diesel stations. Yangon City Electricity Supply Board and Electric Supply Enterprise also implement system improvement and expansion of distribution systems.

(iv) The Department of Hydropower Planning is in charge of planning hydropower projects to be implemented by both the government and through the private sector.

(v) The Department of Hydropower Implementation has four institutes responsible for design, investigation works, and mechanical works; and seven engineering construction companies capable of construction and installation of large hydropower projects.

(vi) Hydropower Generation Enterprise operates and maintains all the MOEP's hydropower stations and is involved in the operation and maintenance of power plants under joint venture arrangements with the private sector. It also operates the country's only coalfired power plant, with a capacity of $120 \mathrm{MWs}$.

(vii) The Department of Electric Power is responsible for planning, coordination, international relations, and serves as staff of the MOEP. 


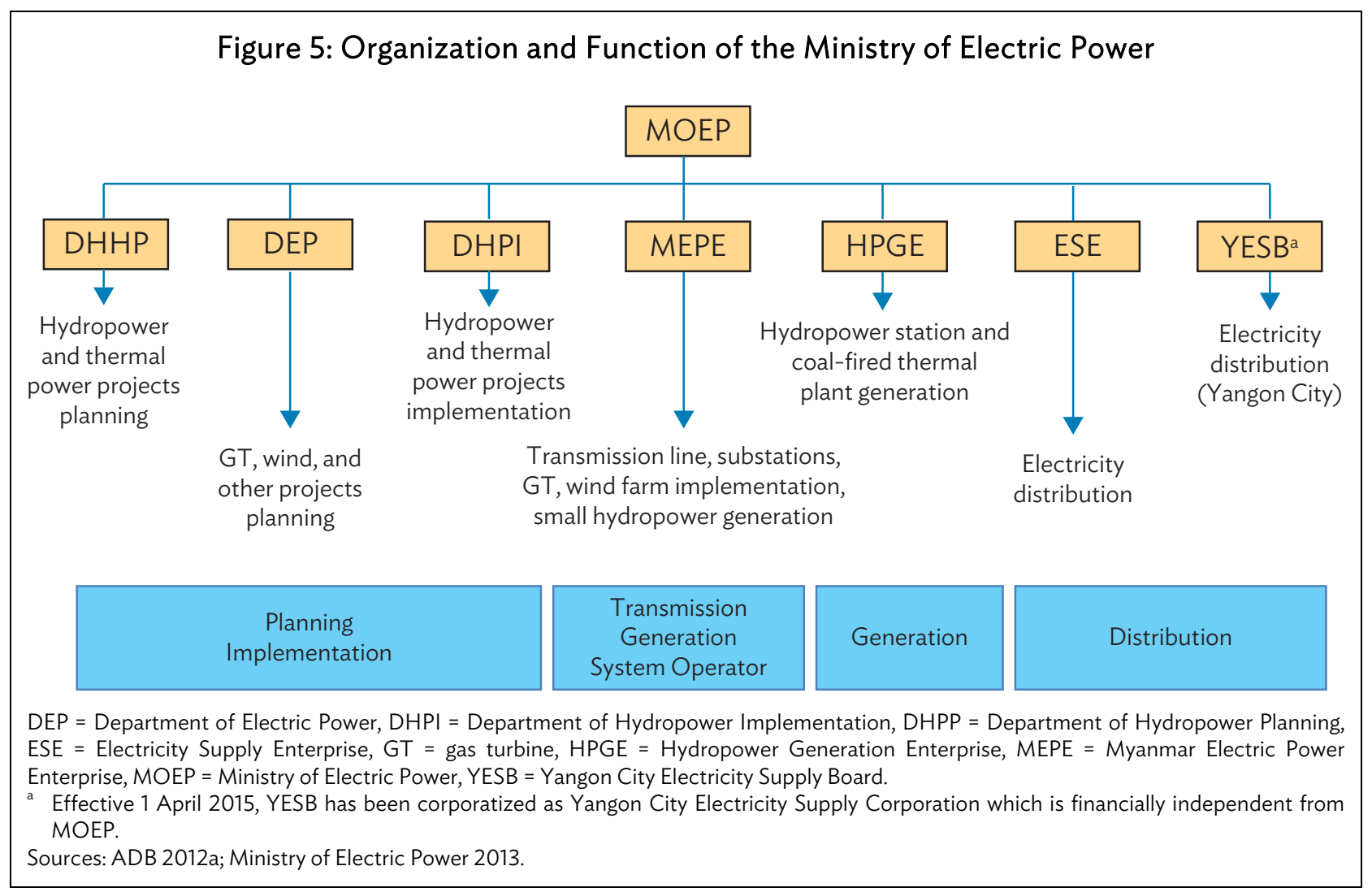

With the restructuring of the MOEP commencing with the corporatization of YESB into Yangon Electricity Supply Corporation, transmission and distribution of power on a township level will be handed over to private sector contractors. The Mandalay Electricity Supply Board has also been transformed into an independent publicly owned firm, Mandalay Electric Corporation, to reduce running costs and national budget deficit.

\section{STATUS AND TRENDS IN THE POWER SECTOR}

\section{A. Capacity and Generation}

Table 1 presents existing capacity and generation by fuel type, while Figures 6 and 7 show the shares of installed capacity by fuel type from 2000 to 2014. Installed capacity grew by a factor of four during 2000-2014 and reached 4,422 MW in 2014, with more than two-thirds coming from hydropower (Figure 6). Despite the increase in installed capacity, available capacity remains limited-1,655 MW, or $40 \%$ of total installed capacity due to periodic scheduled maintenance of power plants and limited availability of water storage facilities for hydropower plants (WEF, ADB, and Accenture 2013, 13). During the dry season, available capacity falls to 1,560 MW (ADB 2013a), or about $36 \%$ of the installed capacity. 
Table 1: Installed Capacity and Generation

\begin{tabular}{|c|c|c|c|c|c|c|}
\hline \multirow{2}{*}{ Power Plants } & \multicolumn{2}{|c|}{ Installed Capacity ${ }^{\mathrm{a}}$} & \multicolumn{2}{|c|}{ Firm Capacity ${ }^{b}$} & \multicolumn{2}{|c|}{ Annual Production ${ }^{c}$} \\
\hline & $(\mathrm{MW})$ & $(\%)$ & $(\mathrm{MW})$ & $(\%)$ & (GWh) & $(\%)$ \\
\hline Hydro & 3,005 & 68 & 986 & 59 & 8,823 & 75 \\
\hline Coal & 120 & 3 & 27 & 2 & 569 & 5 \\
\hline Gas & 1,236 & 28 & 642 & 39 & 2,794 & 23 \\
\hline $\begin{array}{l}\text { Minihydro and } \\
\text { solar } \\
\text { Oil }\end{array}$ & $\begin{array}{r}5 \\
56\end{array}$ & $\begin{array}{l}0 \\
1\end{array}$ & $\begin{array}{l}\ldots \\
\ldots\end{array}$ & $\begin{array}{l}\ldots \\
\ldots\end{array}$ & $\begin{array}{l}\ldots \\
61\end{array}$ & $\begin{array}{l}\ldots \\
\ldots\end{array}$ \\
\hline Total & 4,422 & 100 & 1,655 & 100 & 12,247 & 100 \\
\hline
\end{tabular}

... = not available, $\mathrm{GWh}=$ gigawatt - hour, $\mathrm{MW}=$ megawatt.

${ }^{a}$ Installed capacity is as of 2014. Minihydro and solar account for $0.11 \%$ of installed capacity. Hydropower includes installed capacity for export of $520 \mathrm{MW}$ at maximum.

${ }^{\mathrm{b}}$ Firm capacity is as of July 2013.

${ }^{c}$ Annual production is for 2013-2014. Oil accounts for about 0.5\%.

Notes: There are 23 hydropower plants in operation with installed capacity higher than $10 \mathrm{MW}$, and some 40 mini and microhydropower plants with a total capacity of $34 \mathrm{MW}$. Only four hydropower plants have units larger than $50 \mathrm{MW}$. There is only one coal-fired power plant of capacity $120 \mathrm{MW}$. Of the gas plants, $213 \mathrm{MW}$ were installed by independent power producers in 2013.

Sources: ADB 2013d; Central Statistical Organization 2015; Ministry of Electric Power, as presented in ADB 2012a subsequently updated in ADB 2013a, ADB Forthcoming.

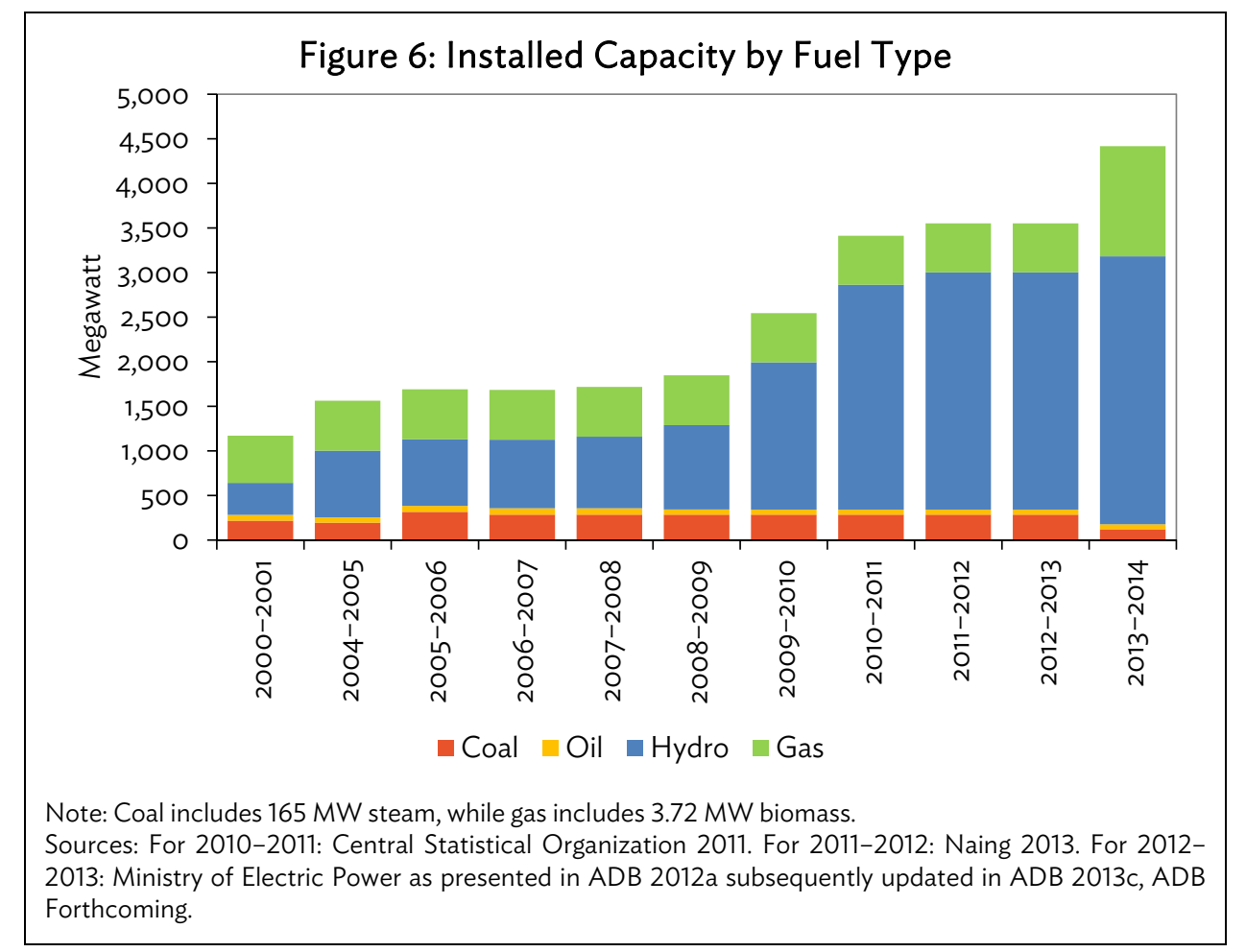

Electricity production has doubled from 5,100 GWh in 2000-2001 to about 12,200 GWh in 2013-2014 (Figure 7). On average, total generation increased annually by $6.4 \%$ over the period. Hydropower's share in total generation grew from $37 \%$ in $2000-2001$ to $72 \%$ in $2013-2014$, or 8,800 GWh. Gas contributed $23 \%$ and coal $5 \%{ }^{5}$

5 Estimates based on the Ministry of Electric Power as presented in ADB (2012a) and Aye (2013). Details are presented in Appendix 3. 


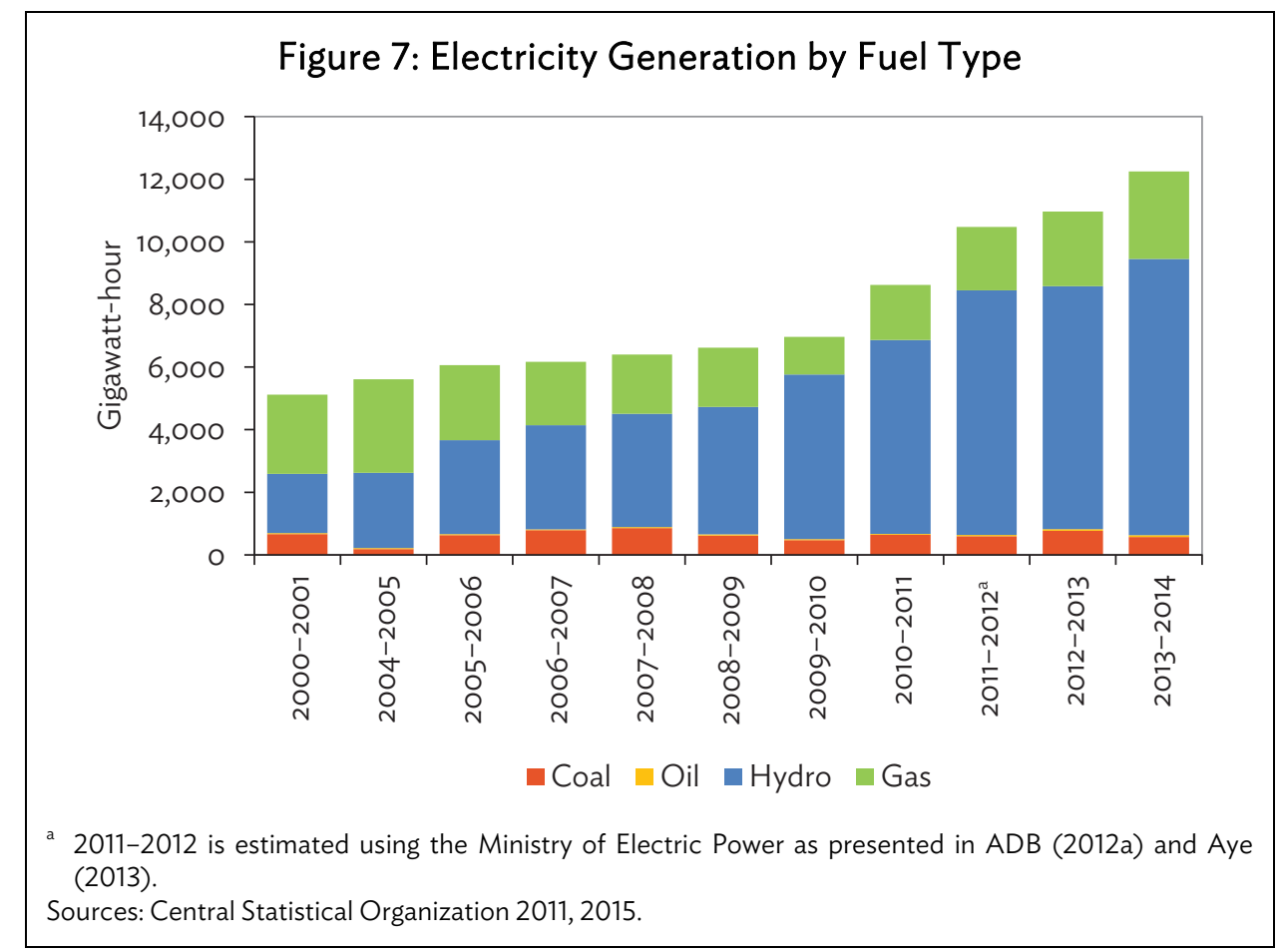

Peak load or demand has been rising in the last 7 years. During 2009-2014, it increased $15 \%$ on average (Figure 8). Peak load reached 1,790 MW in 2012, 2,001.3 MW in 2013, and 2,400 in 2014. Table 2 shows peak load by region and state. The demand for power exceeded the available capacity of the system and coupled with unstable frequency control, frequent load shedding (usually between 8:00 am and 11:00 am) has been a common occurrence. Worse, some regions suffer blackouts lasting 12 to 16 hours (Sharma 2013).

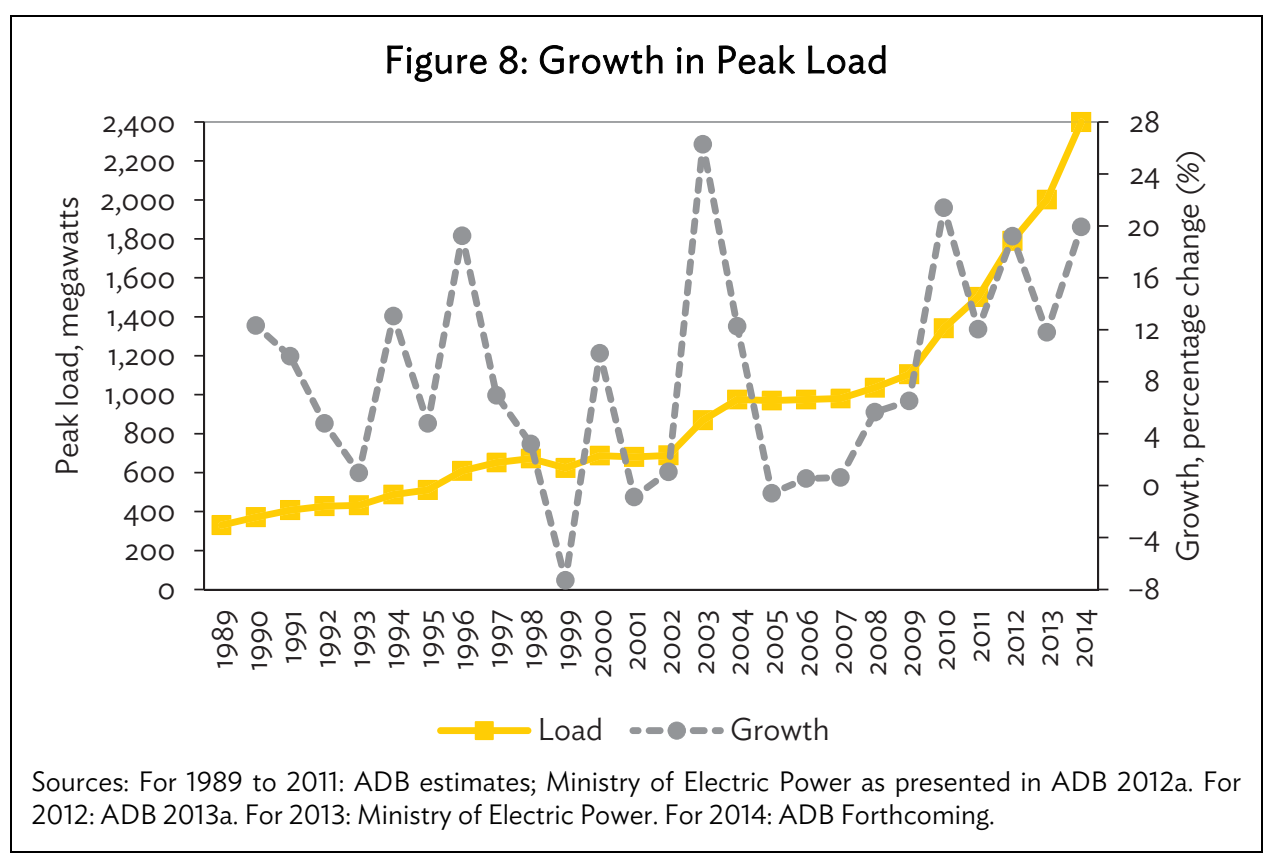


Table 2: Peak Load in Region and State, 2013

(MW)

\begin{tabular}{lr}
\hline Region/State & Peak Load \\
\hline Yangon & 832.70 \\
Mandalay & 358.64 \\
Bago & 136.24 \\
Magway & 107.22 \\
Nay Pyi Taw & 106.23 \\
Sagain Region & 95.83 \\
Ayeyarwaddy & 79.02 \\
Shan (South) & 71.21 \\
Mon & 64.73 \\
Shan (North) & 51.52 \\
Kayin & 36.50 \\
Shan (East) & 14.25 \\
Tanintharyi & 13.20 \\
Kayar & 11.32 \\
Rakhine & 10.80 \\
Kachin & 7.85 \\
Chin & 4.00 \\
\hline Total & $2,001.26$ \\
\hline
\end{tabular}

$M W=$ megawatt.

Source: Ministry of Electric Power.

Based on the 2010-2011 data from the MOEP, household electricity consumption accounted for $42 \%$ of the total, followed by industrial and commercial users with $36 \%$ and $20 \%$, respectively. Power consumption in the industrial sector grew most rapidly during the period, at $6.9 \%$ annual average, followed by the commercial (4.9\%), and transport sectors (2.3\%) (ADB 2012b).

Augmenting power supply remains an MOEP priority. In the last 50 years, exploration and exploitation of hydropower resources has made hydropower the major source of power generation. ${ }^{6}$ And the MOEP has identified 302 potential hydropower project sites with a combined capacity of 46,331 MW (Tables 3 and 4). In addition, about 40,000 MW of potential capacity near the country's borders with Thailand and the PRC could be explored and developed to boost existing capacity and to expand export potential (Table 5). Myanmar has also started tapping renewable sources such as biogas, solar, and wind power. It has installed around 185 biogas digesters of $5 \mathrm{~kW}, 15 \mathrm{~kW}$, and $25 \mathrm{~kW}$ capacities all over the country. Wood chip gasifiers of $30 \mathrm{~kW}$ and $50 \mathrm{~kW}$ capacities have been installed in rural areas and universities for research, and wind and solar energy technologies are being piloted to augment power generation sources. These types of renewable generation projects entail high initial investments, however, and their development remains experimental for now (ADB 2013c).

Table 3: Hydropower Resources

\begin{tabular}{lcc}
\hline Capacity & $\begin{array}{c}\text { Number of Potential } \\
\text { Sites }\end{array}$ & $\begin{array}{c}\text { Potential Capacity } \\
(\mathrm{MW})\end{array}$ \\
\hline Less than 10 MW & 210 & 231.25 \\
Between 10 MW and 50 MW & 32 & 806.30 \\
More than 50 MW & 60 & $45,293.00$ \\
Total & 302 & $46,330.55$ \\
\hline
\end{tabular}

$\mathrm{MW}=$ megawatt.

Source: Ministry of Electric Power as presented in WEF, ADB, and Accenture 2013.

6 Out of 10,000 MW hydropower potential, installed capacity stands at 2,660 MW. 
Table 4: Hydropower Potential by River Basin (including tributaries)

\begin{tabular}{cccc}
\hline Number & River Basin & $\begin{array}{c}\text { Number of Promising } \\
\text { Hydropower Projects }\end{array}$ & $\begin{array}{c}\text { Installed Capacity } \\
(\mathrm{MW})\end{array}$ \\
\hline 1 & Ayeyarwaddy & 34 & 21,821 \\
2 & Chindwin & 8 & 3,015 \\
3 & Sittaung & 11 & 1,128 \\
4 & Thanlwin & 21 & 17,641 \\
5 & Mekong & 4 & 720 \\
6 & Others & 14 & 1,776 \\
\hline Total & & 92 & 46,101 \\
\hline
\end{tabular}

$M W=$ megawatt.

Source: Ministry of Electric Power as presented in ADB 2012a.

Table 5: Potential Hydropower Plants near Myanmar’s Borders

\begin{tabular}{lclr}
\hline & Northern Borders & & Other Borders \\
\hline Project & Capacity (MW) & Project & Capacity (MW) \\
\hline Myitsone & 6,000 & Dapein-2 & 168 \\
Chipwi & 3,400 & Kunlong (Upper Thanlwin) & 1,400 \\
Wutsok & 1,800 & Naopha & 1,000 \\
Kawnglanghpu & 2,700 & Mantong & 200 \\
Yenam & 1,200 & Shweli-2 & 520 \\
Pisa & 2,000 & Ken Tong & 96 \\
Laza & 1,900 & Wan Ta Pin & 25 \\
Chipwinge & 99 & So Lue & 165 \\
Gawlan & 100 & Mong Wa & 50 \\
Wu Zhongze & 60 & Keng Yang & 28 \\
Hkankawn & 140 & He Kou & 88 \\
Tongxinqiao & 320 & Namkha & 200 \\
Lawngdin & 435 & Mong Ton (Upper Thanlwin) & 7,110 \\
Tamanthi & 1,200 & Htu Kyan & 105 \\
Nam Tamhpak (Kachin) & 200 & Henna & 45 \\
& & Tha Kwa & 150 \\
& & Palaung & 105 \\
& & Bawlake & 180 \\
& & Nam Tamhpak & 180 \\
\hline Total & & Ywathit & 4,000 \\
\hline
\end{tabular}

$M W=$ megawatt.

Source: RTE International 2010.

Myanmar's generation system used to consist only of isolated grids, and suppliers were limited to diesel generators and minihydropower. The country pursued medium-scale hydropower development in stages beginning in 1960, with an $84 \mathrm{MW}$ power plant that could supply $595 \mathrm{GWh}$ of electricity to Yangon and Mandalay. The second stage, starting in 1974, added another $84 \mathrm{MW}$ power plant with $596 \mathrm{GWh}$ annual average supply. Eight more hydropower plants, each with installed capacity ranging from $12 \mathrm{MW}$ to $75 \mathrm{MW}$, were commissioned between 1974 and 2005. Development of larger capacity power plants only started in 2005. During 2005-2011, another eight power plants were built, with total installed capacity of 1,934 MW, including two large-scale hydropower plants with a combined capacity of 1,390 MW-Shweli-1 commissioned in 2008 and Yeywa in 2010. Shweli-1 augments domestic supply with $50 \%$ of its total generating capacity and exports the remainder to the PRC. 
The government continues to build, operate, and manage minihydropower plants to provide off-grid power. Currently, 32 minihydropower plants with total generating capacity of $33.1 \mathrm{MW}$ supply power to villages and small industries not connected to the grid. But off-grid power supply is intermittent and usually provides an average of just 2 hours per day, especially in remote areas.

Although Myanmar has abundant gas resources, the output of its nine gas-fired power plants has fallen short of expectations. Combined capacity of these gas-fired plants is $678 \mathrm{MW}$, or $19 \%$ of the country's total installed capacity. ${ }^{7}$ The high nitrogen content of gas from the country's offshore and onshore gas fields, however, has resulted in a low calorific value, which has power plants operating well below their average capacity factor of $70 \%{ }^{8}$ In addition, gas-powered plants need to be shutdown frequently for maintenance, while gas pipelines lack compression, adding to the inefficiency of gasfired plants.

The country operates only one coal plant, with $120 \mathrm{MW}$ installed capacity, about 3\% of total generation. The only coal power plant, Tigyit, in the central part of the country and commissioned in 2002 generates 217 GWh to 389 GWh of electricity annually, or an average capacity factor of only $31 \%$. This is way below ideal operating capacity of $75 \%-80 \%$, again suggesting inefficiencies in operation. Appendix 4 presents available technologies of producing electricity in Myanmar.

\section{B. Transmission and Distribution System}

The transmission system consists of an interconnected overhead grid of $230 \mathrm{kV}, 132 \mathrm{kV}$, and $66 \mathrm{kV}$ (Table 6). The transmission lines are mostly single circuits, and the structural designs mostly lattice steel towers, with a variety of portal and conventional, freestanding towers. Some have overhead lightning protection earthwires. Assessment suggests the transmission lines are still in good condition, but transmission of power over long distances through the $230 \mathrm{kV}$ lines has resulted in significant decreases in voltage of up to 10\%. Table 7 presents transmission losses during 2007-2013.

Table 6: Existing Transmission Lines, 2013

\begin{tabular}{|c|c|c|c|}
\hline \multirow{2}{*}{ Voltage (kilovolt) } & \multirow{2}{*}{ Number of Lines } & \multicolumn{2}{|c|}{ Length } \\
\hline & & (miles) & (kilometers) \\
\hline 230 & 47 & $1,983.33$ & $3,139.86$ \\
\hline 132 & 40 & $1,406.19$ & $2,263.04$ \\
\hline 66 & 163 & $2,859.67$ & $4,602.19$ \\
\hline Total & 250 & $6,249.18$ & $10,057.09$ \\
\hline
\end{tabular}

Source: Ministry of Electric Power.

It includes $165 \mathrm{MW}$ steam and 3.72 MW biomass.

8 Calorific value is the amount of heat released when a specified amount of a substance is burned. 
Table 7: Transmission Losses

\begin{tabular}{|c|c|c|c|c|}
\hline Year & $\begin{array}{c}\text { Net } \\
\text { Transmitted } \\
\text { Energy (GWh) }\end{array}$ & $\begin{array}{c}\text { Net Received Energy } \\
\text { Distribution Side } \\
\text { (GWh) }\end{array}$ & $\begin{array}{l}\text { Energy } \\
\text { Losses } \\
\text { (GWh) }\end{array}$ & Losses $(\%)$ \\
\hline 2013 & 11,386 & 10,853 & 533 & 4.68 \\
\hline 2012 & 10,567 & 9,820 & 747 & 7.07 \\
\hline 2011 & 9,812 & 9,041 & 771 & 7.86 \\
\hline 2010 & 7,614 & 7,042 & 573 & 7.52 \\
\hline 2009 & 6,665 & 6,167 & 499 & 7.48 \\
\hline 2008 & 6,281 & 5,921 & 361 & 5.74 \\
\hline 2007 & 6,007 & 5,588 & 419 & 6.93 \\
\hline
\end{tabular}

$\mathrm{GWh}=$ gigawatt-hour.

Source: For 2012-2013: Ministry of Electric Power. For 2007-2011: Ministry of Electric Power, as presented in ADB 2012a.

The country has about 250 transmission lines, extending 10,057 kilometers (kms), and of these, around $66 \%$ are still $66 \mathrm{kV}$ systems. Only about 47,230 kV systems exist, running 3,140 kms, most of them originating around Yangon and running north. One line runs north from the four combined-cycle gas turbine stations around Yangon (Hlawga, Thaketa, Ywama, and Ahlone), for example, which run along Route 1 up to Bago and then connect to Thazi. Another line traverses the same corridor as Route 2, starting from the same point near Yangon, running north, but then turning west of the Bago Yoma forest, up to the Shwe Daung gas turbine, and then to the town of Taungdwingyi. The $132 \mathrm{kV}$ transmission lines run mainly to the north of the $230 \mathrm{kV}$ systems and cover about 2,263 kms, while the $66 \mathrm{kV}$ lines are mostly in the east (See Appendix 2).

Cross-border connections have been established to export power from the 600-MW Shweli-1 Hydropower Plant and from the Dapein Hydropower Plant to the PRC. A study of future cross-border power connections within the Greater Mekong Subregion suggests potential export from Myanmar to the PRC may reach 100 TWh, which would require between 20-30 gigawatts of transmission capacity. However, authorities have made no definite decision on specific routes or the schedule of construction (ADB 2013c). Thailand may well also import more power in the future; the same study noted that some $6,000 \mathrm{MW}$ of transmission capacity will be required if the additional export of power should materialize. Again, it is unclear what will be the exact routes of these transmission lines (RTE International 2010). To expand the entire network, some have noted, mechanisms should be established to finance these transmission lines and to ensure they form an integral part of the transmission network.

Currently, plans exist to introduce the $500 \mathrm{kV}$ transmission lines that will connect the majority of the country's generation facilities, predominately located in the north, with the main load centers in the south. The government also plans to construct additional $230 \mathrm{kV}, 132 \mathrm{kV}$, and $66 \mathrm{kV}$ transmission lines.

On the distribution side, the system comprises a network of $33 \mathrm{kV}, 11 \mathrm{kV}$, and $6.6 \mathrm{kV}$ originating from the grid and zone substations and connecting to the distribution transformers, which then supply single and three phase 400/230 volt to connected customers (Table 8). The $33 \mathrm{kV}$ is used to connect $33 / 11 \mathrm{kV}$ zone substations and in the future could be used to directly supply 33/0.4 kV distribution transformers. The majority of the existing $6.6 \mathrm{kV}$ lines, mostly in Yangon, are already outdated and need to be phased out and replaced with those capable of handling higher voltage to improve the efficiency of the distribution network and reduce losses. 
Table 8: Existing Distribution Lines and Substations, 2013

\begin{tabular}{|c|c|c|c|}
\hline \multirow{2}{*}{ Voltage (kilovolt) } & \multicolumn{2}{|c|}{ Length } & \multirow{2}{*}{$\begin{array}{c}\text { Capacity } \\
\text { (megavolt-ampere) }\end{array}$} \\
\hline & (miles) & (kilometers) & \\
\hline 33 & $4,543.14$ & $7,311.48$ & $4,630.55$ \\
\hline 11 & $9,930.56$ & $15,016.08$ & $5,079.79$ \\
\hline 6.6 & 838.83 & $1,349.97$ & $1,503.17$ \\
\hline 0.4 & $12,908.28$ & $20,773.85$ & $\ldots$ \\
\hline Total & $28,220.81$ & $44,451.39$ & $11,213.51$ \\
\hline
\end{tabular}

... = unknown.

Source: Ministry of Electric Power.

The sizes of the distribution transformers vary from 100 kilovolt amperes (kVA) to 1,000 kVA and most are still in working condition. In urban areas, some of the transformers are installed indoors in substation buildings; the rest are either ground-mounted or on single- or two-pole structures. The lowvoltage network comprises a 400/230 volt three-phase, four-wire system with the neutral solidly grounded. Frequency is nominally 50 hertz. The construction of the system is generally overhead, with base and open-wire construction using concrete poles. Some distribution is underground, mainly in the Yangon metropolitan area. Many of the distribution structures are also outdated and considered insufficient for present-day loads. In addition, construction designs need to adopt modern, more reliable, and efficient protection systems.

Myanmar also has yet to introduce the more efficient aerial bundled conductor. Many service connections still use impractical twisted connections, which will lead to high resistance connections, resulting in high losses and ultimately burnout and failure of the conductor. Although distribution losses have improved over the last 5 years, they remain in double digits (Table 9). In response, the government plans to upgrade several $6.6 \mathrm{kV}$ systems to $11 \mathrm{kV}$, and expand the $33 \mathrm{kV}$ network by 400 kms, the $11 \mathrm{kV}$ network by $360 \mathrm{kms}$, and the $6.6 \mathrm{kV}$ network by $250 \mathrm{kms}$ (Sharma 2013).

Table 9: Distribution Losses

(\%)

\begin{tabular}{cc}
\hline Year & Losses \\
\hline 2013 & 12.5 \\
2012 & 16.7 \\
2011 & 19.2 \\
2010 & 19.6 \\
2009 & 19.4 \\
2008 & 22.3 \\
2007 & 21.6 \\
\hline
\end{tabular}

Sources: Ministry of Electric Power; ADB 2012a.

\section{POWER SECTOR CONSTRAINTS}

\section{A. Limited, Unreliable Supply of Electricity Constrains Private Investment and Affects the General Population}

Electricity consumption for all types of consumers is low because generating plants have limited capacity to meet growing demand. Per capita electricity consumption is the lowest among Myanmar's 
regional peers, and about $70 \%$ of the population has limited or no access to electricity. Even major cities like Yangon still experience power outages, limiting economic activity.

The current generation mix is highly dependent on hydropower (75\% of the total in 2012). Yet, despite abundant hydropower, natural gas, and renewable alternatives, Myanmar has not developed these because of concerns about environmental impact, resettlement and ethnicity-related issues, and the large capital requirements for implementation.

Seasonal variation in rainfall also does not help, with a prolonged dry season keeping hydropower plants from generating at full capacity. Indeed, the power grid experiences frequent load shedding during the dry season, of up to $500 \mathrm{MW}$ (ADB 2012b). And limited resources for upgrading and maintenance and high fuel costs keep gas- and coal-fired plants significantly below potential capacity. Continued reliance on fuel wood, which accounts for $90 \%$ of traditional biomass used, also threatens forests and, thus, environmental sustainability. In the meantime, emergency gas plants have been installed and more are being procured to address summer load shedding.

High system losses from the outdated transmission and distribution infrastructure compound supply problems, highlighting the need for comprehensive least cost generation planning for the whole country to address deficient electricity supply (ADB 2012b).

\section{B. Limited Electricity Access Hinders Inclusive Growth}

The number of electrified towns and villages in Myanmar has increased slightly, but electrification remained low overall at around 34\% as of 2014. Yangon region, has the highest electrification (78\%), with Kayah State (46\%), Mandalay (40\%), and Nay Pyi Taw (39\%) following (Figure 9). Extremely low rural electrification in several divisions or states is a particular concern, such as in Rakhine State (in the southwest) and areas east of Yangon and in the Ayeyarwaddy Delta. Even for those with access to power, supply is intermittent; wealthier districts get an average of just 6 hours of power per day, and poorer districts only 1 hour (WEF, ADB, and Accenture 2013). Under the national target of universal access by 2030, the government approved the National Electrification Plan in September 2014, providing for an aggressive grid electrification rollout program and an ambitious off-grid program.

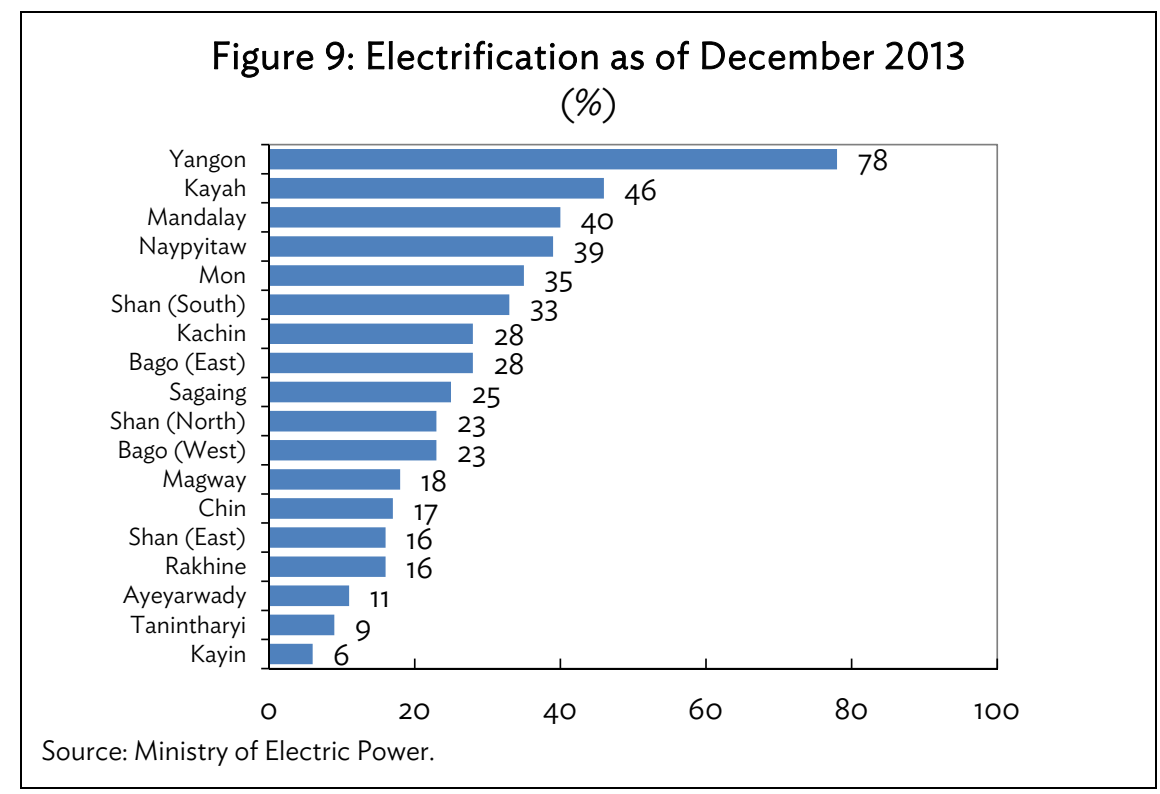


As of 2013, Yangon, as the biggest city, accounts for $50 \%$ of total electricity consumption, with Mandalay a distant second with 17\%. The country's capital, Nay Pyi Taw, consumes about $6 \%$ of electricity (Table 10).

Table 10: Power Consumption in Region and State, 2013

\begin{tabular}{lcc}
\hline Region and State & $\begin{array}{c}\text { Power Consumption } \\
(\text { GWh })\end{array}$ & $\begin{array}{c}\text { Share of Total } \\
(\%)\end{array}$ \\
\hline Yangon Region & $5,031.5$ & 49.8 \\
Mandalay Region & $1,740.8$ & 17.2 \\
Nay Pyi Taw & 558.7 & 5.5 \\
Magway Region & 493.9 & 4.9 \\
Sagaing Region & 448.0 & 4.4 \\
Ayeyarwaddy Region & 324.3 & 3.2 \\
Bago Region (East) & 280.4 & 2.8 \\
Shan State (South) & 276.0 & 2.7 \\
Mon State & 209.5 & 2.1 \\
Bago Region (West) & 199.6 & 2.0 \\
Shan State (North) & 183.6 & 1.8 \\
Kayin State & 157.8 & 1.6 \\
Shan State (East) & 67.8 & 0.7 \\
Kachin State & 49.9 & 0.5 \\
Kayar State & 36.0 & 0.4 \\
Tanintharyi Region & 29.1 & 0.3 \\
Rakhine State & 20.3 & 0.2 \\
Chin State & 4.7 & 0.0 \\
\hline Total & $10,111.9$ & 100.0 \\
\hline
\end{tabular}

$\mathrm{GWh}$ = gigawatt-hour.

Source: Ministry of Electric Power.

Rising electrification may not immediately drive industrial development, but it could spur the growth of micro and small and medium enterprises or home businesses, especially in rural areas.

It could also improve quality of life: lighting increases study time for students, improves the study environment for school children, and can cut time allotted to household chores, freeing time for other work or leisure. More electricity will also boost access to information.

\section{Electricity is Largely Affordable, but Low Cost is Unsustainable in the Long Run}

Myanmar's electricity tariff is among Southeast Asia's lowest, making electricity especially affordable to residential and commercial end users (Figure 10). The government has raised tariffs several times over the years, most recently with effect on 1 April 2014. ${ }^{9}$

9 Current electricity tariff rates are as follows: (i) For households: Mk35/kWh or $\$ 0.036 / \mathrm{kWh}$ (for consumption until 100 kWh), Mk40/kWh or $\$ 0.04 / \mathrm{kWh}$ (for 101-200 kWh), and Mk50/kWh or $\$ 0.05 / \mathrm{kWh}$ (for $201 \mathrm{kWh}$ and above); and (ii) For industry: $M \mathrm{k} 75 / \mathrm{kWh}$ or $\$ 0.08 / \mathrm{kWh}$ (until $500 \mathrm{kWh}$ ), Mk100/kWh or $\$ 0.10 / \mathrm{kWh}$ (for 501-10,000 kWh), Mk125/kWh or $\$ 0.13 / \mathrm{kWh}$ (for 10,001-50,000 kWh), Mk150/kWh or $\$ 0.16$ (for $50,001-200,000$ ), Mk125/kWh or $\$ 0.13 / \mathrm{kWh}(200,001-300,000 \mathrm{kWh})$, and Mk100/kWh or $\$ 0.10 / \mathrm{kWh}(300,001 \mathrm{kWh}$ and above). 


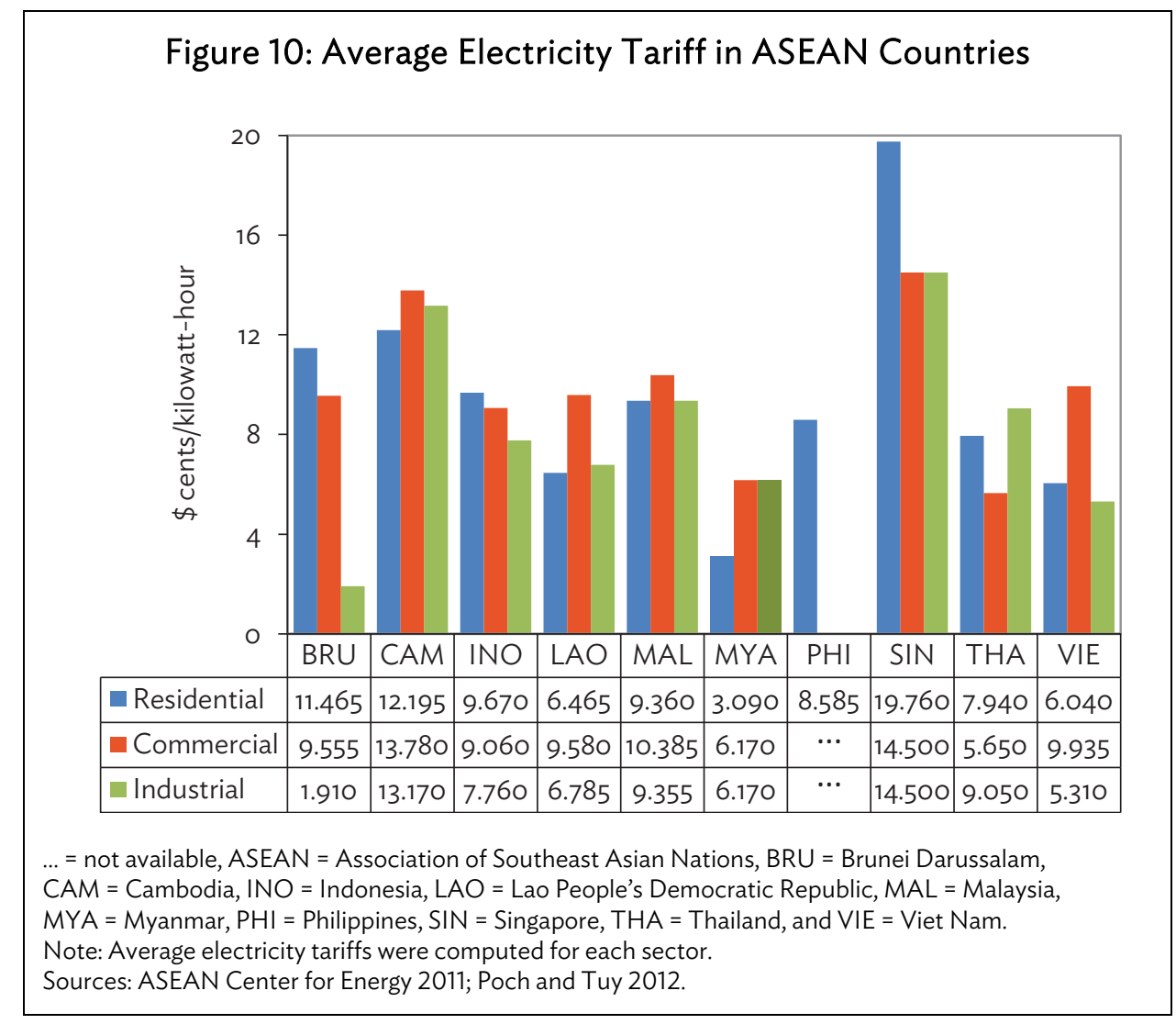

Off-grid consumers pay tariffs varying by the cost of generation by type of power plant, with tariffs ranging between Mk100 and Mk300 per kWh (or between $\$ 0.10$ and $\$ 0.31 / \mathrm{kWh}$ ).

The price of electricity appears to be lower in Myanmar for users that consume at most 500 $\mathrm{kWh}$, compared to other countries in the region, mainly because of the government-controlled pricing policy, which does not reflect the true cost of generation. The government spends around Mk185 billion annually to cover both generation and distribution costs. Including transmission costs, the estimated cost per kilowatt should be at least Mk125/kWh (Song 2013). These subsidies, which are provided to sustain the continuous operation of power plants, strain fiscal capacity and discourage private power producers from investing and expanding operations, knowing that the present tariff structure will not generate enough profit.

Affordable tariff rates, however, do not necessarily ease access to electric power. Private households applying for electricity connection not only face long waiting times, but must also shoulder the initial connection fee of Mk100,000 (excluding the costs of internal wiring and related materials and service charges). This is considered high for most people outside urban areas. Those eventually connected to the central grid, as noted, suffer frequent planned and unplanned power cuts, as well as low power quality. Diesel generators, the alternative, can prove very costly in the long run (Bodenbender, Messinger, and Ritter 2012).

The tariff has been set in response to equity objectives and thus, government sets tariffs for its services, especially those in power, to make them affordable to the general public. Government usually sets fixed tariffs below cost, preventing the agency or the government operator from modernizing and expanding operations, leaving the sustainability of operations and upgrading of its facilities mainly 
dependent on government subsidies. Lack of tariff adjustments, especially because the infrastructure network needs refurbishment and upgrading to cater to growing needs, also threatens service efficiency. And the implicit subsidy is a fiscal burden for already stretched government.

\section{Absence of Systematic Planning and Programming, Poor Governance, and Inadequate Funding Aggravate the Inefficient Management of the Sector}

\section{Institutional overlaps and the lack of a regulatory framework impede power sector development.}

When the institutional structure of a sector is fragmented and composed of many ministries, roles and responsibilities usually overlap. Duplication of function creates so-called jurisdictional grey areas, with consequences if these overlaps are not addressed. When two government ministries or agencies lack coordination and compete or disagree over issues, for example, it considerably diminishes the impact of their respective actions and raises costs. Most importantly, overlaps and redundancies cost the public, which suffers through inadequate or inefficient services.

No one ministry oversees the various requirements of the entire sector, with no clear lines of responsibility, making assignment of responsibilities illogical at times. Given the number of ministries and departments, including state-owned enterprises involved in managing a sector, it will be difficult to gain the agreement needed to institute new policy directives, programs, and administrative reforms.

The need for a separate and independent power regulator in charge of regulating issues such as tariff setting, competition, and so on, has also been consistently raised as an important short-term issue hindering progress. The new Electricity Law does not grant the ERC the tariff-setting function.

2. The lack of overall sector and subsector policies, strategies, and a master plan has resulted in poor prioritizing of capital investments.

An inadequate and inefficient infrastructure system is one result of not institutionalizing the formulation of overall sector or subsector master plans. These lay out the policies and strategies, including targets and options that an institution will implement over a period given the objectives. The lack of a comprehensive plan that identifies and implements priority investment projects, especially in poor and remote areas, has held back the expansion of infrastructure investments.

Capital investment and budget decisions in Myanmar are therefore centralized and not based on any approved sector plan, making for uncoordinated or underinvestment in electricity infrastructure in unserved areas.

3. The poor capacity of institutions in planning, programming, and prioritization of capital investments, and in monitoring and management of sector programs and projects, has contributed to sector inefficiencies.

Personnel in the power sector, after long isolation, have not benefitted from exposure to international developments, and no regular program has been instituted to upgrade their capabilities for planning, operating, and managing assets, and identifying sector needs. Personnel must also be able to plan and conduct economic and financial-related due diligence to guide decision makers on capital related investments. 
4. Inadequate funding (capital expenditures, and operations and maintenance) have left power-related infrastructure in poor condition.

Every developing country's resource envelope is limited. The large financing needs of Myanmar's competing sectors severely constrain the overall budget. The programming and budgeting framework of sector ministries is not prepared based on a medium-term expenditure framework, wherein it identifies and prioritizes capital and recurrent requirements. And because programming of requirements is not synchronized with expected funding over the medium-term, the sustainability even of existing assets is threatened, with funding for upgrading, and operations and maintenance neither timely nor regular.

5. Limited fiscal space has constrained capital investment in the power sector and, more importantly, private sector investment has also been limited in the last few decades.

State-owned enterprises still provide most electricity, and although there is a role for private sector in providing electricity services, no formal public-private partnership framework exists to facilitate that participation in the power sector.

\section{RECOMMENDATIONS}

\section{A. Establish the Governance and Institutions to Effectively Oversee and Manage the Sector}

\section{Short- and medium-term measures}

(i) Assess current institutional structure.

- Review the mandates of each ministry and identify constraints to effective execution of functions.

- Assess technical and financial capacity of each ministry.

(ii) Streamline the ministries involved in the power sector. Ensure the clarity of each ministry's role and remove overlapping functions. Institute reforms that promote cooperation and coordination among ministries.

(iii) Promote collaboration between national and regional governments in planning and implementing power development projects.

(iv) Ensure that appropriate legislative frameworks are updated as needed and accompanying implementing rules and regulations are proposed and adopted as early as possible.

(v) Establish an appropriate regulatory framework and create an independent regulatory body that will (1) promulgate and approve rules and regulations of the power sector, (2) screen and approve power purchasing agreements, (3) approve tariff proposals and wheeling charges, and (4) issue licenses to electricity industry participants, among other regulatory functions. The new Electricity Law already provides for the establishment of the Electricity Regulatory Commission (ERC) but with limited functions.

(vi) Develop a legal and institutional framework for the participation of the private sector in the power sector.

(vii) Formulate a policy framework for the development of renewable energy sources.

- Develop a database of renewable energy data. 
- Map potential renewable energy projects and prioritize them appropriately. Estimate corresponding investment requirements.

- Consider providing subsidies during the initial phase of the renewable energy development program.

- Encourage research and development efforts on renewable energy and facilitate development of appropriate technologies.

\section{Medium- to long-term measures}

(i) Enhance the planning, research, and statistical capacities of ministries through regular training and the hiring of technically competent staff.

(ii) Establish a reliable, relevant, and timely information database that will be available to policy makers and the public, and produced according to international standards and methodologies.

\section{B. Prepare and Implement a Least Cost Power Expansion Plan for Power Sector Development}

\section{Short- to medium-term measures}

(i) Conduct a detailed and comprehensive assessment of the power sector's performance, which should include (1) an assessment of performance of current power infrastructure; (2) projection of short-, medium- and long-term power demand and supply; (3) an assessment of infrastructure capacity building needs; (4) strategies to address identified needs; (5) estimates of investment requirements; and (6) funding sources. It may be noted that master plans for power and rural electrification have already been completed and are for implementation.

(ii) Hold stakeholder consultations to better understand constraints in the sector and to gather support for needed reforms.

(iii) Promote decentralized power generation to reduce energy losses and delivery cost.

(iv) Rehabilitate and upgrade coal and gas-fired generation plants to augment existing supply. Expedite committed construction of additional coal and gas-fired power generation plants.

(v) Promote the development of renewable power sources, namely hydropower, biomass, wind, and solar power.

(vi) Rehabilitate and upgrade existing transmission and distribution lines. Start the construction of the high voltage $(500 \mathrm{kV})$ transmission line to improve efficiency of the system.

(vii) Consider construction of coal-fired plants using clean coal technology.

\section{Medium- to long-term measures}

(i) Implement the power sector reform plan and monitor progress of implementation.

(ii) Develop new sources of generation. 


\section{Aim for Sustainable Electrification}

(i) Conduct regular scheduled maintenance activities of power plants and the grid system to improve efficiency.

(ii) Implement international standards in operating generation, transmission, and distribution systems to improve efficiency and mitigate negative environmental impacts.

(iii) Improve the implementation of energy efficiency and conservation measures.

- Secure technical and financial assistance from development partners to aid in the development of an effective energy efficiency program.

- Ensure effective implementation of demand-side management plans to enhance energy efficiency.

- Build capacity to implement energy efficiency and conservation regulations.

(iv) Rationalize the use of the least efficient generating equipment.

D. Augment Investments in the Power Sector

(i) Tap the private sector and promote public-private partnerships. ADB has initiated work on public-private partnership framework development with the MOEP.

(ii) Rationalize the tariff structure to reduce fiscal burdens and to improve the financial sustainability of power generation. Consider increasing the electricity tariff for industrial users and households with high electricity consumption.

(iii) Reform electricity subsidies, ensuring a more targeted system.

\section{E. Improve Access to Electricity}

(i) Promote rural electrification. Commendably, the government adopted the policy of achieving full electrification by 2030 to be delivered by a commercially operated power industry using private and public sector resources.

- Develop off-grid, mini and microhydropower, biomass, wind, and solar energy systems for rural areas.

- Collaborate with local communities in developing and implementing rural electrification programs.

(ii) Secure access to electricity of poor households through electricity assistance mechanisms (such as direct cash transfer, provision of energy coupons) that will target vulnerable households only.

\section{DEMAND AND INVESTMENT GAP IN MYANMAR POWER INFRASTRUCTURE}

Economic growth in Myanmar is expected to average at least 6.8\% a year in coming years, given potential and the interest it has garnered from investors all over the world. This will raise demand for power or electricity services for consumption and production. Failure to respond will constrain growth and slow poverty alleviation. The country's infrastructure development has lagged considerably behind, making it important to estimate the demand for electricity that will result from the expected growth in income. Expanding basic power-related infrastructure to address additional electricity supply will require huge capital investment. This section estimates these financing needs. 


\section{A. Methodology and Data}

The demand gap is measured as the difference of projected infrastructure stock level and the current stock of infrastructure. For the power sector, projections of installed capacity up to 2030 are based on ADB estimates in collaboration with the MOEP in Myanmar, calibrated from power generation. Its projections are based on gross domestic product (GDP), population, urbanization, and crude oil prices, which represent the low-growth scenario averaging an annual installed capacity growth rate of $12 \%$. The high-growth scenario has an average annual installed capacity growth rate of $13 \%$.

The investment gap measures the investment requirement of the future new capacity and replacement of existing infrastructure. To compute the investment gap, unit costs based on most recent best practice prices are applied to the infrastructure flows, or the change in infrastructure stock levels (Table 11). Moreover, costs of maintenance and replacement of total capacity are also projected in the covered period.

\section{Table 11: Unit Cost of Power Infrastructure Services ${ }^{a}$}

(\$)

\begin{tabular}{l} 
Low High \\
\hline 1,000
\end{tabular}

\section{B. Results}

Based on the projected stock levels for the power sector, Table 12 presents projected demand up to 2030.

\section{Table 12: Need Gaps from Projections of Power Infrastructure Stock Levels with Baseline Stock of 1.7 Gigawatts in 2010}

(GW, unless otherwise indicated)

\begin{tabular}{lrr}
\hline & 2020 & 2030 \\
\hline Low-growth scenario $^{a}$ & & 15.0 \\
Stock & 4.9 & 13.3 \\
Gap & 3.2 & 782.4 \\
Change from 2010 (\%) & 188.2 & 19.2 \\
High-growth scenario & & 17.5 \\
Stock & 5.7 & $1,029.4$ \\
Gap & 4.0 & \\
Change from 2010 (\%) & 235.3 & \\
\hline
\end{tabular}

$\mathrm{GW}=$ gigawatt

${ }^{a}$ Low-growth scenario refers to $12 \%$ average growth rate for installed capacity for the power sector.

${ }^{b}$ High-growth scenario refers to $13 \%$ average growth rate for installed capacity for the power sector.

Source: ADB calculations. 
Based on the 2010 levels of power infrastructure stock, demand will increase 1.9 times in 2020 and 7.8 times in 2030 under the low GDP growth scenario and 2.4 times in 2020 and 10.3 times in 2030 under the high GDP growth scenario.

Table 13 presents investment gaps for new capacity and replacement needs in the power sector. During 2014-2030, Myanmar's investment gap is $\$ 15.2$ billion to $\$ 22.7$ billion, translating to around $\$ 0.9$ billion to $\$ 1.3$ billion annually under the low-growth scenario. Under the high-growth scenario, around $\$ 19.7$ billion to $\$ 29.6$ billion, or $\$ 1.2$ billion to $\$ 1.7$ billion annually will be required. This annual increase in power infrastructure spending is equivalent to 2.1\%-3.0\% of GDP based on 2012 GDP level of $\$ 55.8$ billion (IMF 2014), a huge challenge. ${ }^{10}$ About $\$ 2$ billion in power investments is currently under implementation.

Table 13: Power Investment Gaps from New Capacity and Replacement Needs, 2014-2030 (\$ billion)

\begin{tabular}{|c|c|c|c|c|}
\hline & \multicolumn{2}{|c|}{ Using Low Unit Cost } & \multicolumn{2}{|c|}{ Using High Unit Cost } \\
\hline & & Annual & & Annual \\
\hline & $2014-2030$ & Average & 2014-2030 & Average \\
\hline Low-growth scenario ${ }^{a}$ & 15.2 & 0.9 & 22.7 & 1.3 \\
\hline High-growth scenariob & 19.7 & 1.2 & 29.6 & 1.7 \\
\hline
\end{tabular}

a Low growth scenario refers to $12 \%$ average growth rate for installed capacity for the power sector.

b High growth scenario refers to $13 \%$ average growth rate for installed capacity for the power sector.

Source: ADB calculations.

To become competitive and expand its production networks, Myanmar will need adequate and efficient supply of electricity. The empirical study here yielded more or less similar results as other projections of Myanmar's infrastructure requirements, despite some differences in sectors selected." But the above estimates do not include the financing requirements needed for operation and maintenance of new infrastructure projects.

Nevertheless, it is important for the country to develop innovative financing mechanisms and modalities to be able to fund these huge requirements, since Myanmar may not be able to mobilize domestic resources to fund these projects. This is why private sector financing is very important. To attract private sector financing, these power projects need to be translated into financially viable and bankable projects. At the same time, the government is responsible for ensuring that policies and the regulatory environment remain stable, and institutions that manage these infrastructure sectors such as power are able to efficiently contribute to the country's output.

10 In this Myanmar study, investment gaps for infrastructure (inclusive of power, transport, and information and communications technology sectors) could total as much as $\$ 80$ billion by 2030 .

11 For example, Myanmar's total estimated investment needs in power, transport, telecommunications, excluding internet but including water and sanitation, amount to $\$ 21.7$ billion for $2010-2020$ or $\$ 2$ billion per year. With this amount, about $58 \%$ is needed for power (Bhattacharyay 2010). Per McKinsey Global Institute (2013), between 2010 and 2030 , Myanmar needs to invest $\$ 320$ billion or $\$ 16$ billion per year in infrastructure, which includes residential and commercial real estate, power plants, water treatment plants, and road and rail networks, if the economy is to achieve $8 \%$ growth a year. 


\section{APPENDIX 1: ENERGY-RELATED GOVERNMENT INSTITUTIONS AND THEIR RESPONSIBILITIES}

1. Ministry of Environmental Conservation and Forestry: fuel wood, climate change, and environmental standards and safeguard requirements, but not social ones.

2. Ministry of Agriculture and Irrigation: biofuels and microhydropower for irrigation purposes.

3. Ministry of Science and Technology: research and development related to renewable energy technologies.

4. Ministry of Mines: coal production.

5. Ministry of Industry: energy efficiency and off-grid rural energy access (it contains the Rural Energy Supporting Development Committee), as well as approving electrical connections for businesses and industries (this may change with the approval of the new Electricity Law).

6. Ministry of National Planning and Economic Development: takes part in the formulation of national development plans and contributes to the economic development of the state.

\footnotetext{
From WEF, ADB, and Accenture 2013.
} 


\section{APPENDIX 2: MYANMAR'S TRANSMISSION SYSTEM}

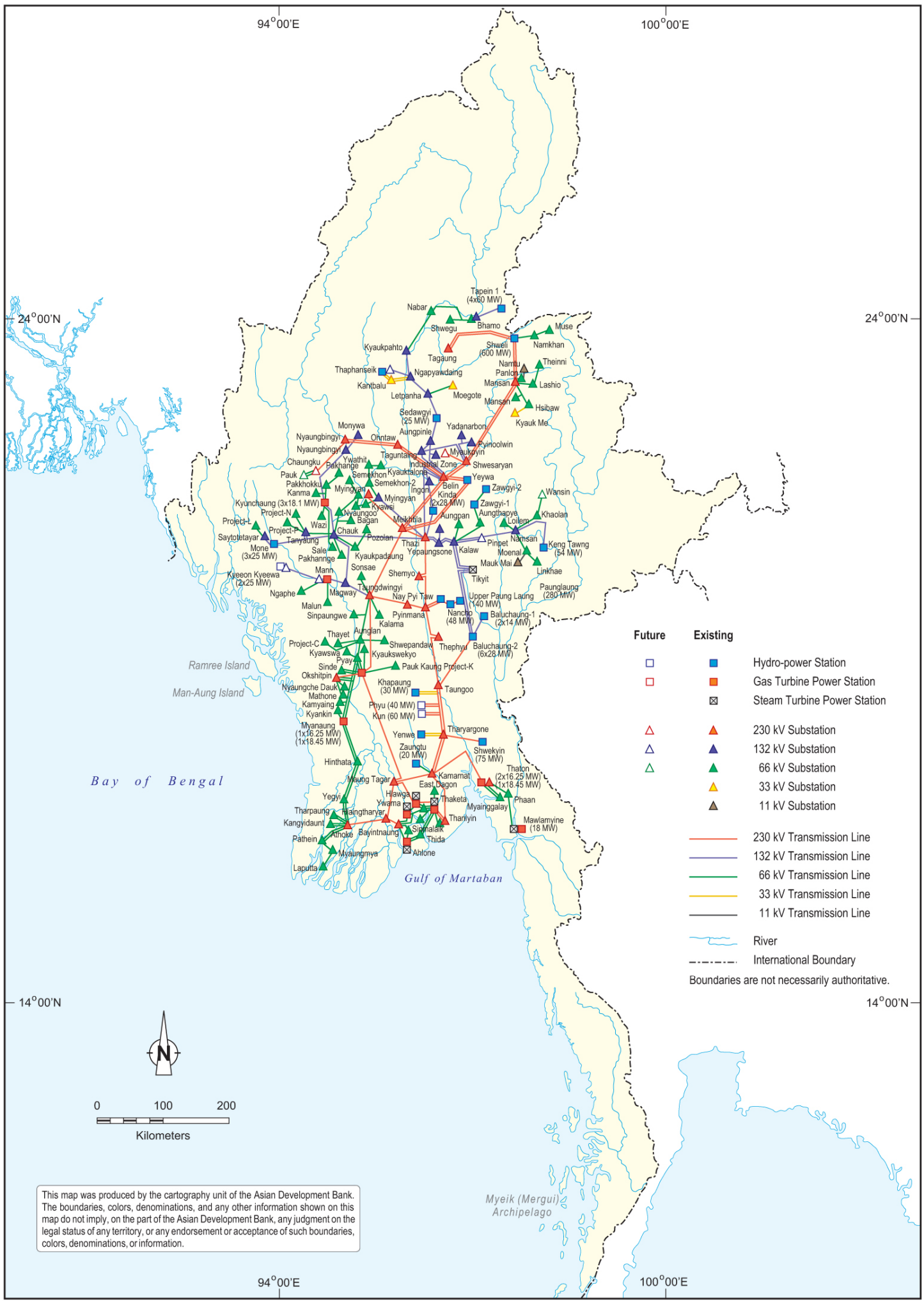

$k \mathrm{~V}=$ kilovolt.

Source: Ministry of Electric Power as presented in ADB 2012a. 


\section{APPENDIX 3: PRODUCTION OF ELECTRIC POWER}

\begin{tabular}{|l|c|c|c|c|c|c|}
\hline & Generation & Unit Loss & $\begin{array}{c}\text { Departmental } \\
\text { Use }\end{array}$ & $\begin{array}{c}\text { Net } \\
\text { Production }\end{array}$ & $\begin{array}{c}\text { Cost of } \\
\text { Production }\end{array}$ & Unit Cost \\
\cline { 2 - 7 } & $(\mathrm{GWh})$ & $(\mathrm{GWh})$ & $(\mathrm{GWh})$ & $(\mathrm{GWh})$ & $(\mathrm{MK} 000)$ & $(\mathrm{MK})$ \\
\hline $1990-1991$ & $2,643.05$ & 934.28 & 33.57 & $1,675.20$ & 812,892 & 0.49 \\
\hline $1995-1996$ & $3,762.33$ & $1,437.21$ & 62.75 & $2,262.37$ & $1,771,341$ & 0.78 \\
\hline $2000-2001$ & $5,117.64$ & $1,747.84$ & 101.86 & $3,267.94$ & $22,610,627$ & 6.92 \\
\hline $2004-2005$ & $5,608.24$ & $1,618.68$ & 80.38 & $3,909.18$ & $9,648,221$ & 2.47 \\
\hline $2005-2006$ & $6,064.16$ & $1,630.29$ & 81.21 & $4,352.66$ & $13,336,809$ & 3.06 \\
\hline $2006-2007$ & $6,164.15$ & $1,727.16$ & 82.00 & $4,354.99$ & $99,163,940$ & 22.77 \\
\hline $2007-2008$ & $6,398.02$ & $1,821.75$ & 138.18 & $4,438.09$ & $111,703,936$ & 25.17 \\
\hline $2008-2009$ & $6,621.76$ & $1,767.14$ & 153.36 & $4,701.26$ & $125,941,881$ & 26.79 \\
\hline $2009-2010$ & $6,964.27$ & $1,855.93$ & 114.98 & $4,993.36$ & $133,362,959$ & 26.71 \\
\hline $2010-2011$ & $8,625.11$ & $2,157.81$ & 155.22 & $6,312.08$ & $162,715,007$ & 25.78 \\
\hline
\end{tabular}

$\mathrm{GWh}=$ gigawatt-hour, $\mathrm{MK}=$ kyat.

Note: Electricity production is estimated at 10 terawatt hours in 2011-2012 (WEF, ADB, and Accenture 2013).

Source: Central Statistical Organization 2011. 
APPENDIX 4: ELECTRICITY PRODUCTION BY TECHNOLOGY

\begin{tabular}{|c|c|c|c|c|c|c|c|}
\hline \multirow{2}{*}{$\begin{array}{l}\text { Type } \\
\text { Hydropower }\end{array}$} & \multirow{2}{*}{$\begin{array}{c}\text { Power Station } \\
\text { Baluchaung BHP (1) }\end{array}$} & Location & \multirow{2}{*}{$\begin{array}{c}\text { Operation } \\
\text { Start Date } \\
1992\end{array}$} & \multicolumn{2}{|c|}{$\begin{array}{l}\text { Installed Capacity } \\
\text { (MW) }\end{array}$} & \multirow{2}{*}{$\begin{array}{c}\begin{array}{c}\text { Firm } \\
\text { Capacity }^{\mathrm{a}}\end{array} \\
140\end{array}$} & \multirow{2}{*}{$\begin{array}{r}\begin{array}{c}\text { Annual } \\
\text { Production }\end{array} \\
200.0\end{array}$} \\
\hline & & Kayah & & $2 \times 14$ & 28.0 & & \\
\hline & Baluchaung BHP (2) & Kayah & 1974 & $6 \times 28$ & 168.0 & 20.0 & $1,190.0$ \\
\hline & Kinda & Mandalay & 1985 & $2 \times 28$ & 56.0 & 20.0 & 165.0 \\
\hline & Sedawgyi & Mandalay & 1989 & $2 \times 12.5$ & 25.0 & 12.0 & 134.0 \\
\hline & Zawgyi (1) & Shan & 1995 & $3 \times 6$ & 18.0 & 6.0 & 35.0 \\
\hline & Zawgyi (2) & Shan & 1998 & $2 \times 6$ & 12.0 & 5.0 & 30.0 \\
\hline & Zaungtu & Bago & 2000 & $2 \times 10$ & 20.0 & 15.0 & 76.0 \\
\hline & Thaphanseik & Sagaing & 2002 & $3 \times 10$ & 30.0 & 20.0 & 117.2 \\
\hline & Mone & Magwe & 2004 & $3 \times 25$ & 75.0 & 190.0 & 330.0 \\
\hline & Paunglaung & Mandalay & 2005 & $4 \times 70$ & 280.0 & 30.0 & 911.0 \\
\hline & Ye'new & Bago & 2007 & $2 \times 12.5$ & 25.0 & 15.0 & 123.0 \\
\hline & Khabaung & Bago & 2008 & $2 \times 15$ & 30.0 & 15.0 & 120.0 \\
\hline & KengTawn & Shan & 2008 & $3 \times 18$ & 54.0 & 175.0 & 377.6 \\
\hline & Shweli (1) & Shan & 2008 & $6 \times 100$ & 600.0 & 38.0 & $4,022.0$ \\
\hline & Yeywa & Mandalay & 2010 & $4 \times 197.5$ & 790.0 & 630.0 & $3,550.0$ \\
\hline & Tapein $(1)^{\mathrm{b}}$ & Kachin & 2011 & $4 \times 60$ & 240.0 & 30.0 & $1,065.0$ \\
\hline & Shwegyin & Bago & 2011 & $4 \times 18.8$ & 75.2 & 35.0 & 262.0 \\
\hline & Kun & Bago & 2011 & $3 \times 20$ & 60.0 & 38.0 & 190.0 \\
\hline & Kyee ON Kyee Wa & Magwe & 2012 & $2 \times 37$ & 74.0 & 70.0 & 370.0 \\
\hline \multicolumn{2}{|l|}{$\begin{array}{l}\text { Subtotal } \\
\text { hydropower }\end{array}$} & & & & $2,660.2$ & $1,504.0$ & $13,267.8$ \\
\hline \multirow{2}{*}{$\begin{array}{l}\text { Coal-fired } \\
\text { Subtotal coal- } \\
\text { fired }\end{array}$} & Tigyit & Shan & 2005 & $2 \times 60$ & 120.0 & 26.7 & 600.0 \\
\hline & & & & & 120.0 & 26.7 & 600.0 \\
\hline \multirow[t]{15}{*}{ Gas turbine } & Kyunchaung & Magwe & 1974 & $3 \times 18.1$ & 54.3 & 44.5 & 300.0 \\
\hline & Mann $^{c}$ & Magwe & 1978 & $2 \times 18.45$ & 36.9 & 0 & 0 \\
\hline & Myanaung & Ayarwaddy & $\begin{array}{l}1975 \\
1984\end{array}$ & $\begin{array}{l}1 \times 16.25 \\
1 \times 18.45\end{array}$ & 34.7 & 14.5 & 200.0 \\
\hline & Shwedaung & Bago & 1984 & $3 \times 18.45$ & 55.35 & 36.5 & 300.0 \\
\hline & Ywama & Yangon & 1980 & $2 \times 18.45$ & 70.3 & 31.0 & 238.0 \\
\hline & & & 2004 & $1 \times 24$ & & & \\
\hline & & & 2004 & $1 \times 9.4$ & & & \\
\hline & Thakayta & Yangon & $\begin{array}{l}1990 \\
1997\end{array}$ & $\begin{array}{l}3 \times 19 \\
1 \times 35\end{array}$ & 92.0 & 68.5 & 568.0 \\
\hline & Ahlone & Yangon & 1995 & $3 \times 33.3$ & 154.2 & 91.0 & 990.0 \\
\hline & & & 1999 & $1 \times 54.3$ & & & \\
\hline & Hlawga & Yangon & 1995 & $3 \times 33.3$ & 154.2 & 97.0 & 990.0 \\
\hline & & & 1999 & $1 \times 54.3$ & & & \\
\hline & Thaton & Mon & 1985 & $1 \times 18.45$ & 50.95 & 40.0 & 300.0 \\
\hline & & & 2001 & $2 \times 16.25$ & & & \\
\hline & Mawlamyaing & Mon & 1980 & $2 \times 6$ & 12.0 & 3.6 & 60.0 \\
\hline $\begin{array}{l}\text { Subtotal gas } \\
\text { turbine }\end{array}$ & & & & & 714.9 & 427.0 & $3,946.0$ \\
\hline Total & & & & & $3,495.0$ & $1,958.0$ & $17,814.0$ \\
\hline
\end{tabular}

$M W=$ megawatt.

a Capacity as of August 2012.

b Temporarily out of service.

c Production stopped in 2005

Notes: In addition to the 3,495 MW above, the sector also has 63.02 MW oil and 3.72 MW biomass. All these sum up to 3,561.74 MW. The total capacity of gas at 714.9 MW includes steam of $165 \mathrm{MW}$.

Source: Ministry of Electric Power as presented in ADB 2012a. 


\section{REFERENCES}

ASEAN Centre for Energy. 2011. Electrical Tariffs in ASEAN Member Countries. Jakarta Selatan.

Asian Development Bank (ADB). 2012a. Myanmar: Energy Sector Initial Assessment. Manila.

2012b. Sector Assessment (Summary): Energy. In Interim Country Partnership Strategy: Myanmar, 2012-2014. Manila.

2013a. Sector Assessment (Summary): Energy. In Report and Recommendation of the President to the Board of Directors: Power Distribution Improvement Project. Manila.

- 2013b. Enhancing the Power Sector's Legal and Regulatory Framework Project Data Sheet: Details. http://adb.org/projects/details?page=details\&proj_id=46486-001

- 2013c. Assessment of the Greater Mekong Subregion Energy Sector Development: Progress, Prospects, and Regional Investment Priorities. Manila

2013d. Republic of the Union of Myanmar: Capacity Development and Institutional Report, Consultant's report. Manila (TA 8244).

_. Forthcoming. Myanmar Energy Sector Assessment, Strategy, and Roadmap. Manila.

Aye, K. N. 2013. Country Presentation of Myanmar at the JICA Tokyo International Center Energy Policy Training Program. Tokyo. 23 June-13 July.

Bhattacharyay, B. 2010. Estimating Demand for Infrastructure in Energy, Transport, Telecommunications, Water and Sanitation in Asia and the Pacific: 2010-2020. ADBI Working Paper No. 248. Tokyo: Asian Development Bank Institute.

Bodenbender, M., C. Messinger, and R. Ritter. 2012. Mission Report: Energy Scoping Myanmar. April and May. EUEl: Energy for Development.

Central Statistical Organization. 2011. Statistical Yearbook 2011-Myanmar Data on CD-ROM.

2015. Selected Monthly Economic Indicators, May 2015. Nay Pyi Taw. https://www.csostat .gov.mm/excelfile/p2.4MA02.xls

Directorate of Investment and Company Administration (DICA). Data and Statistics. http://dica.gov .mm.x-aas.net/ (accessed September 2015).

Fay, M. and T. Yepes. 2003. Investing in Infrastructure, What is Needed from 2000-2010. World Bank Policy Research Working Paper 3102. Washington, DC: World Bank.

Greater Mekong Subregion Statistics. http://www.gms-eoc.org/gms-statistics/lao-pdr

International Energy Agency (IEA). 2012. World Energy Outlook 2012. Paris.

_. International Energy Agency database. http://www.iea.org/statistics/ 
International Monetary Fund (IMF). 2014. Myanmar: Second Review under the Staff-Monitored Program-Staff Report and Press Release. IMF Country Report No. 14/91. March. http://www.imf .org/external/pubs/ft/scr/2014/cr1491.pdf

Lui, J., N. Nair, and B. L. Paisner. 2013. Turning on the Lights in Myanmar. 13 March. Project Finance International. http://www.blplaw.com/expert-legal-insights/articles/wp-content/uploads/2013/ 04/PFI-BLP-by-line.pdf

McKinsey Global Institute. 2013. Myanmar's Moment: Unique Opportunities, Major Challenges. McKinsey and Company.

Ministry of Electric Power. 2013. Country Presentation of Myanmar. Powerpoint presentation at the JICA Tokyo International Center for the Energy Policy Training Program in Tokyo, 23 June-13 July. http://eneken.ieej.or.jp/data/5022.pdf

Data on primary energy supply, final energy consumption, transmission and distribution lines, transmission and distribution losses, peak loads, power consumption, and electrification rates provided to authors.

Naing, K. S. S. 2013. Fuel-Mix Requirements for Power Generation in Myanmar. Powerpoint presentation in Yangon. 29 January.

Poch, K. and S. Tuy. 2012. Cambodia's Electricity Sector in the Context of Regional Electricity Market Integration. In Y. Wu, X. Shi, and F. Kumura, eds. Energy Market Integration in East Asia: Theories, Electricity Sector and Subsidies. Economic Research Institute for ASEAN and East Asia Research Project Report 2011-17. Jakarta.

RTE International. 2010. Update of the GMS Regional Master Plan-Main Report. http://www.adb.org/sites/default/files/related/19812/41018-reg-dpta-03.pdf

Sharma, V. 2013. Overview of the Electricity Industry in Myanmar. Public Sector and Government Practice. Frost and Sullivan. http://www.slideshare.net/VikasSharma128/myanmar-electricityindustrydec2013

Song, S. 2013. Myanmar Announces Electricity Prices Increase, Fears Illegal Cost-Cutting Measures in Response. International Business Times. 5 November.

Webb, S. 2013. Myanmar: Renewable Energy in the Asia Pacific: A Legal Overview (3rd edition)Myanmar. Mondaq. 11 September.

World Bank. World Development Indicators. http://data.worldbank.org/data-catalog/worlddevelopment-indicators

World Economic Forum, ADB, and Accenture. 2013. New Energy Architecture: Myanmar. http://www.adb.org/sites/default/files/publication/30265/new-energy-architecture-mya.pdf 


\section{Power Sector Development in Myanmar}

This paper assesses Myanmar's electricity sector and recommends several concrete policy options to enable government to address issues such as supply security, greater accessibility, and affordability, especially for the poor and disadvantaged. The paper also estimates infrastructure demand and the corresponding investment requirements to narrow the supply gap in the power sector.

\section{About the Asian Development Bank}

ADB's vision is an Asia and Pacific region free of poverty. Its mission is to help its developing member countries reduce poverty and improve the quality of life of their people. Despite the region's many successes, it remains home to the majority of the world's poor. $A D B$ is committed to reducing poverty through inclusive economic growth, environmentally sustainable growth, and regional integration.

Based in Manila, ADB is owned by 67 members, including 48 from the region. Its main instruments for helping its developing member countries are policy dialogue, loans, equity investments, guarantees, grants, and technical assistance. 